\title{
Bursa Yeşil Cami İmamı Hattat İbrâhim Efendi*
}

\begin{abstract}
Semra Güler**
Atıf/@: Güler, Semra, Bursa Yeşil Cami İmamı Hattat İbrâhim Efendi, Artuklu Akademi, 2020/7 (1), 1-28.

Özet: Bursa Yeşil Cami imamı ve aynı zamanda hattat olan İbrâhim Efendi'nin Kütahyalı olduğu bilinir. İbrâhim Efendi'nin hüsn-i hat sanatında hangi silsileden geldiği ve hocasının kim olduğuna dair malumat bulunmamaktadır. Fakat kendisi tarafından yazılmış yazılar, Bursa'nın en önemli camileri olan Ulu Cami, Yeşil Cami ve Yıldırım Cami duvarlarını süslemektedir. Bursa için böylesine önemli mabedlerde yazıları bulunan İbrâhim Efendi'ye kaynaklarda hakkıyla yer verilmemiş olması, bu araştırmayı önemli kılmaktadır. Bu makale; İbrâhim Efendi'nin hayatı ve eserleri hakkında bilgiler içermesinden başka, İbrâhim Efendi'ye ait olabileceği düşünülen eserleri de ihtiva etmektedir. İbrâhim Efendi'ye ait yazı kalıplarıyla desteklenen bu düşünceler neticesinde, İbrâhim Efendi'nin Bursa'ya hizmet etmiş ve eserleri vesilesiyle sanat dünyasında imzasını bırakmış önemli bir hattat olduğu anlaşılmaktadır.
\end{abstract}

Anahtar Kelimeler: Bursa Yeşil Cami, Bursa Ulu Cami, Bursa Yıldırım Cami, Hat Sanat1, Hattat.

\section{Calligrapher Ibrahim Efendi The Imam of Bursa Green Mosque}

Citation/@: Güler, Semra Calligrapher Ibrahim Efendi The Imam of Bursa Green Mosque, Artuklu Akademi, 2020/7 (1),1-28.

\begin{abstract}
It is known that Ibrahim Efendi-the imam of Bursa Green Mosque and also a calligrapher was from Kütahya. There is no information about which art tradition Ibrahim Efendi followed in his calligraphies and who his master was. However, his works of art decorate the walls of the most outstanding mosques of Bursa; the Grand Mosque, Green Mosque and Yildirim Mosque. In comparison to his art-works located in the well-known shrines in Bursa, there is very limited information given in the sources about Ibrahim Efendi. In addition to the data about Ibrahim Efendi's life and works, this study also includes works that are thought to belong to Ibrahim Efendi. The calligraphy patterns of Ibrahim Efendi
\end{abstract}

* Bu makale için kişisel arşivini kullanmama müsaade ettikleri ve paylaştığı bilgiler için Mehmed Safiyyüddin Erhan ile yardımlarından dolayı Neslihan Duran'a teşekkür ederim.

** Dr. Öğretim Üyesi, Kütahya Dumlupınar Üniversitesi İslami İlimler Fakültesi İslam Sanatları Bilim Dalı, semra.guler@dpu.edu.tr. 
support this claim; as a result, it can be argued that Ibrahim Efendi was an influential calligrapher who contributed to art tradition in Bursa and left his mark by his works.

Key Words: Bursa Green Mosque, Bursa Grand Mosque, Bursa Yildirim Mosque, Islamic Calligraphy, Calligrapher.

\section{Giriș}

Bursa'da hüsn-i hat sanatı denildiğinde akla ilk Bursa Ulu Camii'nin gelmesi doğaldır çünkü Bursa Ulu Cami, hem Bursalı hem de İstanbullu önemli hattatların eserlerini bünyesinde barındıran adeta bir hüsn-i hat müzesi gibidir. Cami içindeki büyük payelerin sebep olduğu masif etkiyi dağıtmak adına duvarların yazılarla doldurulduğu tahmin edilmektedir. ${ }^{1}$ Bursa' daki 1855 depremi sonrasında hem var olan yazıların onarımı hem de yeni yazılar için Sultan Abdülmecid Han tarafından görevlendirilen Hattat Abdülfettah Efendi ile Hattat Mehmed Şevkî Efendi'nin çalışmalarıyla Ulu Cami yazıları daha da zenginleştirilmiştir. 1855 depremi sonrasındaki bu faaliyetlerle alakalı Bursa Ulu Cami, pek çok kitaba ve akademik çalışmaya konu olmasına karşın aynı şeyi Bursa'nın diğer önemli mabedleri olan Yeşil Cami ve Yıldırım Cami için söylemek zordur. Zira Yeşil Cami daima ilk yapıldığı döneme ait olan çinileri ve çini üzerine yazılan yazılarıyla öne çıkmıştır. ${ }^{2}$ Yıldırım Cami duvarlarında ${ }^{3}$ mevcud bulunan hüsn-i hat yazılarıyla alakalı ise kaynaklarda çok az bilgiye rastlanmaktadır. ${ }^{4}$

Bu makalenin konusu olan hattat şeyh İbrâhim Efendi'nin hayatıyla alakalı bilgileri ve Yeşil Cami ile Yıldırım Cami duvarında yazıları olduğunu Mehmed Şemseddin (Ulusoy) Efendi'nin Yâdigâr-ı Şemsî isimli eserinden öğreniyoruz. Makalede önce İbrâhim Efendi'nin hayatı ve aile efradı hakkındaki malumata yer verilmiş, sonrasında ise İbrâhim Efendi'nin hat eserlerine değinilmiştir. İbrâhim Efendi'nin Yeşil ve Yıldırım Camileri'ndeki

1 Hicabi Gülgen, “Ulu Cami Hatları Bursa Ulucamii Yazıları”, Bursa'nın Kalbi Ulu Cami, ed. Mustafa Kara Bilal Kemikli, (Bursa: Bursa İl Özel İdaresi Yayınları, 2009), 117.

2 Konuyla alakalı bkz. Abdülhamit Tüfekçioğlu, Erken Dönem Osmanlı Mimarîsinde Yazı, (Ankara: Kültür Bakanlığı Yayınları, 2001), 135-164.

3 Albert Gabriel, Bir Türk Başkenti Bursa isimli eserinde Texier'den alıntı yaparak Yıldırım Cami'nin iç kısmının belli bir yüksekliğe kadar çinilerle bezeli, geri kalan kısmın ise badanalı olduğunu belirtir. Fakat dediğine göre, çiniler zamanla yok olmuştur. Albert Gabriel, Bir Türk Başkenti Bursa, haz. Bir Türk Başkenti Bursa, haz. Neslihan Er, Hamit Er, Aykut Kazancigil (Bursa: Osmangazi Belediyesi Yayınları, 2008), I, 72.

4 Ekrem Hakkı Ayverdi Osmanlı Mi'mârîsi'nin İlk Devri isimli kitabında, mihrap kubbesi duvarlarında yazılar bulunduğunu ve bunların son tamirat sonrasına ait olduklarını yazmakla yetinir. Konu hakkında başka bilgi vermez. Ancak cami içinden çekilmiş fotoğraflarda yazılar görülmektedir. Ekrem Hakkı Ayverdi, Osmanl Mi'mârîsinin İlk Devri (Ertuğrul, Osman, Orhan Gaazîler, Hüdavendigâr ve Ylldırım Bâyezîd 630-805 (1230-1402) I, (İstanbul: İstanbul Fetih Cemiyeti, 1989), 433. 
hat yazıları, 1855 depremi sonrası gerçekleştirilen tamirat sonrasında yapılmış olmaları bakımından da dikkate şayandır. M. Safiyyüddin Erhan'ın özel koleksiyonunda yer alan İbrâhim Efendi'ye ve hattat olan büyük oğlu Mehmed Şevkî Efendi'ye ait yazı kalıpları, baba-oğulun yazılarına ve çalışma usûllerine dair bilgiler içermesi bakımından birer belge hükmündedir. Bu makalenin amacı; Erken Dönem Osmanlı Mimarisi'nin önemli eserleri olan Bursa Yeşil Cami ile Yıldırım Cami'ndeki 1855 Bursa depremi sonrası yazılmış olan hüsn-i hat yazılarının sahibi Hattat İbrâhim Efendi'nin hayatı, ailesi ve içinde bulunduğu tasavvufî/sanatsal muhitiyle ilgili bilgiler vermek, bahsi geçen camiler dışındaki diğer yazılarına dikkat çekmek ve mevzu hakkında elimizde bulunan belge/bilgileri kayda geçmektir.

\section{Hattat İbrâhim Efendi'nin Hayatı}

İbrâhim Efendi'nin kendisi hakkındaki en geniş bilgiler, M. Şemseddin Efendi'nin Yâdigâr-ı Şemsî isimli eseri ${ }^{5}$ ile M. Safiyüddin Erhan'ın arşivinde bulunan İbrâhim Efendi'yle ilgili yazılmış tek sayfalık bilgi notunda 6 (Fotoğraf 1) yer almaktadır. Rik’a hattıyla yazılmış bu bilgilerin kim tarafından ve ne zaman yazıldığı bilinmemektedir. ${ }^{7}$ Her iki kaynaktaki bilgilere göre Kütahyalı olan İbrâhim Efendi'nin ${ }^{8}$ hangi tarihte doğduğuna dair bir kayıt yoktur. İbrâhim Efendi'nin babası Cemâlizâde Seyyid Mehmed Efendi, Kuşadalı İbrâhim Halvetî́ ye ${ }^{9}$ müntesiptir. Seyyid Mehmed Efendi,

5 Mehmed Şemseddin, Bursa Dergâhlan Yâdigâr-ı Şemsî I-II, haz. Mustafa Kara - Kadir Atlansoy, (Bursa: Uludă̆ Yayınları, 1997), 341-342.

6 Sayfanın transkripsiyonu şöyledir;

"Meşhur hattatlardan Cemâlizâde Şeyh Hacı İbrâhim Edhem Efendi Kütahya'dan Bursa'ya hicret eyleyerek Namazgâh Caddesi'nin Müftüönü'ndeki Halvetî Dergâhı'na post-nişîn bulunarak meşâyih-ı kirâmdan Bursalı Şeyh Mehmed Şevkî Efendi'ye intisabla damadi olmuş ve Mehmed Şevkî Efendi'nin vefâtılla yerine mezkûr dergâhda temsilen meşihâte geçmiştir. Başlıca eserleri, Ulu Cami'ne duvar üzerine celî ve sülüs olarak şu hadis-i şerîfi "ekmelü'l-mü'minîne imânen ahsenühüm hulükan" yazmışlardır. Aynca imamı bulundukları Yeşil Câmi'-i şerîfin mihrab tarafindaki karşılıklı duvar üzerine o zamanın valisi bulunan Ahmed Vefik Paşa'nın tertib ve emriyle dairevî ve hendesî bir şekilde gâyet A san'atlı 'Amme Sûresi'ni ve iki yazı dahî yazmışlardır. Bundan başka Yıldırım Câmi'$i$ şerîfinde de aynı şekilde bu sûre-i şerîfi yazmışlardır. Merhûmun birçok levhalar halinde yazıları da vardır. Cemâlizâde lakabın almaları da Kütahya'da meşhur meşâyihdan en büyük dedeleri Şeyh Cemaleddin oğullarına Kütahyahlarca bu lakab verilmiştir. Her nedense "Ben mezara, eserlerim mezara" dedikleri rivâyet edilmektedir.

Halen Bursa'da "Süleyman Çelebi İlkokulu", vaktiyle "Şeyh Ahmed el-Gazzî̀" dergâhı idi. Bunun post nişîni sülâle$i$ Eşrefiyye'den merhum "Şeyh Ali Sırrî" Efendi de ta'lik hattına üstad-ı küll idi. Birçok levha halinde yazıları olduğu gibi bazı kabir taşlarına kitâbeleri vardır."

7 Metin içindeki Hattat Ali Sırrî Efendi'yle ilgili kısımda Bursa'daki Ahmed-i Gazzî Dergâhı'nın Süleyman Çelebi İlkokulu olduğundan bahsedilmesi, yazının hangi tarihlerde yazıldığına dair ipucu verir. Çünkü dergâh binası uzun süre ilkokul olarak kullanılmış ama Kazgânî Mektebi olarak adlandırılmıştır. Okula, Süleyman Çelebi ismi verilmesi 1948 yılından sonrasına aittir. Mustafa Kara, Bursa'da Tarîkatlar ve Tekkeler, (Bursa: Osmangazi Belediyesi Yayınları, 2017), 686-687.

8 İbrâhim Efendi'nin ismi, dipnot $6^{\prime}$ da da görüldüğü üzere İbrâhim Edhem olarak belirtilmiştir.

9 Halvetî-Şâbâniyye tarikatının Kuşadaviyye kolunun kurucusudur. Kuşadalı İbrâhim Efendi'nin tarikat silsilesi, tarikatın pîri Șeyh Şâban Velî’ye (ö. 976/1568) kadar uzanır. Nihat Azamat, "Kușadalı İbrâhim Efendi”, Türkiye Diyanet Vakfi İslâm Ansiklopedisi (DIA) (Ankara: Türkiye Diyanet Vakfı, 2002), XXVI, 468-470. Kuşadalı İbrâhim 
Kuşadalı İbrâhim Efendi'nin Bursalı halifesi Hacı Mehmed Şevkî Efendi'yle ${ }^{10}$ de pirdâştır. Bu hukuk vesilesiyle İbrâhim Efendi, Hacı Mehmed Şevkî Efendi'nin kızı Saide Rukiyye Hanım'la evlenmiş ve Hacı Mehmed Şevkî Efendi'ye damat olmuştur. Hacı Mehmed Şevkî Efendi'nin diğer kızı Tevhide Hanım ise Eşrefzâde/Gazzîzâde İsmâil Gâlib Efendi11 ile evlidir.

İbrâhim Efendi'nin İstanbul Lokmacı Sokağı'nda bulunan Hasan Efendi Dergâhı şeyhi ve Kuşadalı İbrâhim Halvetî́nin halifelerinden Ahmed İzzet Efendi'den hilâfet aldığını, M. Şemseddin (Ulusoy) Efendi Ahmed İzzet Efendi'nin 12 torunu Mehmed Tevfîk Efendi'den Bursa'da bulundukları esnada duyduğunu ifade eder. ${ }^{13}$

İbrâhim Efendi, kayınpederinin ahirete irtihalinden sonra Bursa Setbaşı semtinde bulunan dergâhın ${ }^{14}$ (Fotoğraf 2) meşihatına getirilmiştir. M. Şemseddin (Ulusoy) Efendi Yâdigâr-ı Şemsî'de15, Hacı Mehmed Şevkî Efendi bahsinde İbrâhim Efendi'nin dergâha şeyh tayin edilmesi hakkında şöyle bir hadise anlatır: Mehmed Şevkî Efendi, istidadı yüksek genç bir dervişinin kendisinden sonra halifesi olmasını arzu etmektedir. Ancak bu dervişin babasının mutaassıp bir yapıya sahip olması ve duruma itiraz etmesi işleri karıştırır. Bir gün dervişte bir hal zuhur eder ve dervişin ağzından uygun olmayan sözler çıkar. Durumu fırsat bilen babası Hacı Mehmed Şevki Efendi'ye gelip terbiyesizlik eder. Bunun üzerine Hacı Mehmed Şevkî Efendi genç dervişi yanına çağırır, bir bardak suya okuyup üfledikten sonra gence içirir. Genç derviş o halden çıkıp, normale döner. Fakat olan olmuş, dervişin

Efendi'yle ilgili daha geniş bilgi için bkz. Yaşar Nuri Öztürk, Kutsal Gönüllü Velî Kuşadalı İbrâhim Halvetî (Hayatı, Düşünceleri, Mektuplart), (İstanbul: Fatih Yayınevi, 1982).

10 Bursalı Osman Efendi'nin oğlu olan Hacı Mehmed Şevkî Efendi, Kuşadalı İbrâhim Efendi'den seyr ü sülûkunu tamamlamış ve icâzet almıştır. Yeşil Camii'nde imamlık, kendi ismiyle anılan dergâhında şeyhlik ifa etmiştir. 1858 (H. 1275) senesinde vefât edince Emir Sultan yolundaki Sancaktar Baba Türbesi karşısındaki kabristana defnedilmiştir. Şemseddin, Yâdigâr-ı Şemsî, 339-341; Osmânzâde Hüseyin Vassâf, Sefine-i Evliyâ, haz. Mehmed Akkuş - Ali Yılmaz (İstanbul: Kitabevi, 2006), IV, 126-127; Bedri Mermutlu - Hasan Basri Öcalan, Tarihi Bursa Mezar Taşları II Emir Sultan Mezarlı̆̆ , (Bursa: Bursa Büyükşehir Belediyesi Kültür A.Ş. Yayınları, 2012), 401.

11 Baba tarafından soyu Eşrefoğlu Rûmî hazretlerine, babaannesi cihetiyle ise Ahmed Gazzî hazretlerine dayanır. Her iki aile de Bursa'nın önemli, köklü ve tanınmış ailelerindendir. Hakkında bilgi için bkz. Şemseddin, Yâdigâr-ı Şemsî, 112-113.

12 Şeyh Ahmed İzzet Efendi, Sultan II. Mahmud döneminin önemli şahsiyetlerinden Emin Efendi' nin oğludur ve seyyiddir. Kuşadalı İbrâhim Efendi'den hilâfet almış olup bugün medfun bulunduğu İstanbul Fatih Semti'ndeki Kazasker Refet Efendi tarafından inşa edilmiş olan külliyede görev yapmıştır. Fakirlere ve talebelere yardım etmek hususundaki hassasiyetinden ötürü halk arasında Lokmacı Dede olarak bilinir. "İstanbul/Ahmet İzzet Efendi Külliyesi”, erişim tarihi: 04.03.2020, http://fetihlervakfi.org.tr/faaliyet.php?id=3.

13 Şemseddin, Yâdigâr-l Şemsî, 341.

14 Bursa'nın Setbaşı Semti'nden Namazgâh'a doğru çıkan yokuşun sol cihetinde, Müftüönü Camii karşısında yer alan dergâhın bânisi Hacı Mehmed Şevkî Efendi'dir. Dolayısıyla dergâh, bu isimle de kaynaklarda geçer. Halk arasında Şâbâniye Dergâhı olarak anılması ise Hacı Mehmed Şevkî Efendi'nin Halvetiyye tarîkatının Şâbâniye koluna bağlı bulunmasındandır. Daha geniş bilgi için bkz. Mehmed Safiyüddîn Erhan, Bir Zamanlar Bursa'ydı Bir Pâyitahtın Pâyimâli, (İstanbul: Sufi Kitap, 2016), 237-243.

15 Şemseddin, Yâdigâr-ı Şemsî̀, 340-341. 
halife olma durumu ortadan kalkmıştır. Hacı Mehmed Şevkî Efendi'nin sırlanmasından sonra hanımı Rukiyye Hanım'ın (binti Sadullah) muvafakatiyle damatları Hacı İbrâhim Efendi, 21 Ağustos 1858 (H. 11 Muharrem 1275) tarihinde dergâhın şeyhliğine tayin olunmuştur. Ayrıca, İbrâhim Efendi'nin kayınpederi gibi Yeşil Cami'nde imamlık ifa ettiği Yeşil Cami'deki ketebesinden anlaşılmaktadır.

M. Şemseddin (Ulusoy) Efendi, İbrâhim Efendi'nin şahsiyetinden ve şemâilinden de bahseder ve İbrâhim Efendi' nin kayınpederleri Hacı Mehmed Şevkî Efendi gibi kibar ve nazik bir kişiliğe sahip, hatırnaz ve latifeci olduğunu yazar. Şemâil itibariyle ise uzunca boylu, sakallı, gunneli konuşan ve mütebessim bir çehreye sahiptir. Yine M. Şemseddin (Ulusoy) Efendi'nin anlattığına göre kayınpederi Hacı Mehmed Şevkî Efendi, İbrâhim Efendi'nin şiirle meşgul olmasını ister zira şiirin zihnin açılmasına sebep olduğuna inanır. Ancak, İbrâhim Efendi'nin şairlik hususunda bir istidatları bulunmamakla beraber çalışır, çabalar. Yine de muvaffak olamaz. ${ }^{16}$

İbrâhim Efendi, 18 Temmuz 1889 (H. 20 Zilkade 1306) günü ahirete irtihal eylemiş ve bacanağı İsmâil Gâlib Efendi gibi kayınpederleri Hacı Mehmed Şevkî Efendi'nin yanına yani Emir Sultan'daki Sancaktar Baba olarak bilinen Nimetullah Efendi Türbesi karşına defnolunmuştur ${ }^{17}$. Fakat mezar taşı günümüzde mevcut değildir.

\section{Hattat İbrâhim Efendi'nin Ailesi}

İbrâhim Efendi ve ailesinin Kütahyalı olduğu malumdur. Yukarıda bahsedilen bilgi notundan öğrendiğimize göre, 18 İbrâhim Efendi'nin sülalesinin Cemâlizâde olarak anılması, Kütahya'nın meşhur meşâyihından en büyük dedeleri Şeyh Cemaleddin oğullarına, Kütahyalılarca bu lakabın verilmiş olması sebebiyledir. Yapılan araştırma neticesinde, Şeyh Cemaleddin'in kim olduğuna dair bir bilgiye ulaşılamamıştır. Ama Kütahya'nın en eski mahallelerinden biri olan Cemaleddin Mahallesi'nin ${ }^{19}$ Şeyh Cemaleddin'in ismiyle bir bağlantısı olabilir mi sorusu akla gelir.

İbrâhim Efendi, Kütahya'dan Bursa'ya gelerek Hacı Mehmed Şevkî Efendi' nin kızı Saide Rukiyye Hanım'la evlenmiş ve bu evliliğinden Mehmed

\footnotetext{
Şemseddin, Yâdigâr-l Şemsî, 341-342.

Şemseddin, Yâdigâr-ı Şemsî, 341.

Bkz. dipnot 6 ve Fotoğraf 1.

9 Bilgi için bkz. Mehmet Bayartan, "Osmanlı'dan Günümüze Kütahya Şehrinin Yapı Taşları: Mahalleler", İstanbul Üniversitesi Edebiyat Fakültesi Coğrafya Bölümü Dergisi, 18 (2009): 57-70.
} 
Şevkî Efendi ile Hâfız Osman Efendi dünyaya gelmiştir. Büyük oğlu Mehmed Şevkî Efendi'nin doğumuna Baba Efendi Dergâhn ${ }^{20}$ şeyhi Baha Efendi ${ }^{21}$ tarafından tarih düşürülmüş ve bu tarih 1858 (H. 1275)'dir.22 Mehmed Şevkî Efendi, teyze oğlu Ali Sırrî Efendi ${ }^{23}$ ile birlikte İstanbul'da meskûn Kâdiriyye meşâyihından Üsküdarlı Osman Şems Efendi'ye ${ }^{24}$ intisab etmiştir. Osman Şems Efendi'nin vefâtı sonrasında da halifesi İstanbul Aydınoğlu Dergâhy ${ }^{25}$ şeyhi İzzî Bedreddin Efendi'den ${ }^{26}$ tasavvufî terbiyesini tamamlamakta olduğu zamanlarda, 13 Aralık 1908 (H. 19 Zilkade 1326) günü henüz 50 yaşında iken vefât etmiştir. Dedesi ve babasının yanına sırlanmıştır. Günümüzde mezar taşı mevcut değildir. M. Şemseddin Efendi, Mehmed Şevkî Efendi'yi halim-selim, mütevazı ve sessiz bir kişiliğe sahip bir zat olarak anlatır. ${ }^{27}$

Mehmed Şevkî Efendi'nin babası İbrâhim Efendi gibi hattat olduğu bilinir ve bazı okullarda öğretmenlik de yapmıştır. Hat konusunda hocasının kim olduğuna dair herhangi bir bilgi bulunmamakla birlikte babası olabileceği ihtimali akla gelir. Ancak buna dair bir bilgi ya da belgeye ulaşılamamıştır. Mehmed Şevkî Efendi'nin Bursa Yeşil Cami harim kısmının doğu duvarında bir yazısı mevcuttur. Kırmızı bir çerçeve içinde sülüs harflerle, "el-Cema'atü rahmetün ve'l-furkatü 'azabün" 28 hadis-i şerîfi' ${ }^{29}$ yazılıdır. Yazının tarihi 1875 (H. 1292)'dir. Mehmed Şevkî Efendi, yazıya imzasını "ketebeĥ̂ Şevkî" olarak atmıştır (Fotoğraf 3). M. Safiyyüddin Erhan'ın özel

20 Bursa' da bugünkü postane binasının karşısına Ahmed Baba tarafından inşa edilmiş Nakşibendî tekkesidir. Tekke günümüzde mevcud değildir. Kamil Kepecioğlu, Bursa Kütüğü, trc. Osman Çetin- Mustafa Kara- Mefail Hızlı- Hüseyin Algül- M. Asım Yediyıldız, (Bursa: Bursa Büyükşehir Belediyesi Kültür A.Ş. Yayınları, 2009), I, 165.

21 Baba Efendi tekkesinin banisi ve şeyhi Ahmed Efendi'nin 1903'te vefat eden küçük oğludur. Kepecioğlu, Bursa Kütüğ̈̈, I, 166.

22 "Bezm-i ehl'i-laha Şevkî şevk ile basdı kadem" Şemseddin, Yâdigâr-ı Şemsî, 343.

23 Ali Sırrî Efendi, yukarıda bahsi geçen Hacı Mehmed Şevkî Efendi'nin diğer damadı İsmâil Gâlib Efendi'nin oğludur. Bursa'nın tanınmış önemli hattatlarındandır. Ta’lik yazıyı Mevlevî Zeki Dede'den meşk etmiştir. İstanbul Karacaahmet Mezarlığı'nda, şeyhi Osman Şems Efendi'nin yanında medfundur. İbnülemin Mahmud Kemal İnal, Son Hattatlar, (İstanbul: Maarif Basımevi, 1955), 618-620.

24 Osman Şems Efendi, Kâdiriyye tarîkatının Enveriyye (Şemsiyye) kolunun kurucusu ve Osmanlı Devleti'nin son dönem önemli şairlerindedir. Nihat Azamat, "Osman Şems Efendi", Türkiye Diyanet Vakfi İslâm Ansiklopedisi (DİA) (İstanbul: Türkiye Diyanet Vakf1, 2007), XXIII, 473-475.

25 15. yüzyıl sonu veya 16. yüzyıl başında inşa edildiği tahmin edilen İstanbul Eminönü'ndeki tekkedir. Tekkeden günümüze Ünsî Hasan Efendi'nin türbesi, hazîre, şadırvan ve yıktırıldıktan sonra geriye çekilerek yeniden yaptırılan ihata duvarı kalmıştır. M. Baha Tanman, "Aydınoğlu Tekkesi”, Türkiye Diyanet Vakfi İslâm Ansiklopedisi (DİA) (İstanbul: Türkiye Diyanet Vakfı, 1991), IV, 238-239.

26 Şeyhi Osman Şems Efendi' den Kâdiriyye Tarîkatı Enveriyye kolundan hilâfet almış, şeyhin vefâtı üzerine İstanbul Aydınoğlu Dergâhı'nda irşad faaliyetlerini sürdürmüştür. Osmânzâde Hüseyin Vassâf, Sefine-i Evliyâ, haz. Mehmed Akkuş - Ali Yılmaz, (İstanbul: Seha Neşriyat, 1990), I, 170-173.

27 Şemseddin, Yâdigâr-ı Şemsî, 343.

28 "Cemaatte rahmet, ayrilikta azap vardır."

29 Hadis-i şerîfin sahihliği ile alakalı olarak bkz. Salih Karacabey, "Mesajları ve Muhtevası Açısından Bursa Yeşil Cami ve Türbe İç Yazıları”, Bursa'nın Tarihi Mahalleleri II (Hocataşkın, Kurtoğlu, Meydancık, Namazgah, Yeşil), (Bursa: Bursa Büyükşehir Belediyesi Yayınları, 2011), 138. 
arşivinde Mehmed Şevkî Efendi'ye ait bir yazının kalıbı bulunmaktadır. Kareleme yöntemiyle bölünmüş kâğ1da, sülüs harflerle Esmâü'l-Hüsnâ'dan "yâa $M u$ 'în"30 yazılıdır (Fotoğraf 4). Yazının sadece harf konturları bulunur yani mürekkeple yazılmamıştır. $M u$ 'în'deki $\varepsilon$ harfinin içine "Allah" lafzı, ن harfinin içine de "celle celâluh" yazılmıştır. Ayrıca hattat, tarihi ya' nın altındaki iki noktanın içine bölerek (bir noktanın içine 13, diğerine 03 şeklinde) yazmış, imzasını da $M u \hat{\imath} n^{\prime}$ in altındaki iki noktanın içine yine bölerek (bir noktanın içine ketebeh $\hat{u}$, diğerine Şevkî şeklinde) atmıştır. Belirtildiği üzere yazının tarihi 1885 (H. 1303)'dir.

İbrâhim Efendi'nin küçük oğlu Osman Efendi ise ilk tahsilini ve hâfızlığını tamamladıktan sonra şeyhi İzzî Bedreddin Efendi'ye intisab etmiştir. Bursa'daki Hamam Tekke' nin ${ }^{31}$ meşihatının boş kalması sebebiyle, tekkenin şeyhliği Osman Efendi'nin uhdesine tevcih edilmiştir. Hâfız Osman Efendi, tekkenin tevhidhânesi harap olduğundan selamlık dairesindeki odalardan birinde pazar geceleri Kâdiriyye ve Şabaniyye usûlünü icrâ etmiştir. Kendisinden sonra oğulları Cemal Efendi ile Hakkı Efendi aynı usûlde tekkedeki ayinleri devam ettirmişlerdir. Hâfız Osman Efendi, 8 Mayıs 1908 (H. 6 Rabîulâhir 1326) günü irtihâl eyleyince, dedesi, babası ve ağabeyinin medfun bulunduğu mahale defnedilmiştir. 32 Bugün için mezar taşı bulunmamaktadır. 33

\section{Hattat İbrâhim Efendi'nin Eserleri}

İbrâhim Efendi'ye ait olduğunu tespit ettiğimiz bütün hat eserleri Bursa'dadir. Bunlar arasında, tarihi kesin olarak bilinen tek eseri Bursa Ulu Cami'ndeki yazısıdır. Yeşil Cami'deki yazılarının Ahmed Vefik Paşa'nın müfettişliği zamanında yani 1863-64 yılları arasında yazıldığını tahmin ediyoruz. Yıldırım Cami ile Hacı Mehmed Şevkî Efendi Dergâhı'nda bulunan yazıların tarihleri ise bilinmemektedir. İbrâhim Efendi'nin yazılarını tarih sırasına koyarsak, şöyle sıralamak mümkündür:

1-) Bursa Yeşil Cami harim kısmının doğu ve batı duvarlarındaki İbrâhim Efendi'ye ait yazılarda aynı istifle, aynı ayetler yazılıdır. Yuvarlak

"Yardıma muhtaçlara yardım eden" demektir.

1 Yıldırım Bâyezid'in vezirlerinden Çandarlı Ali Paşa (ö. 809/1406) tarafından Ali Paşa Mahallesi'nde inşa edilmiştir. Tekke adını, Ali Paşa tarafından yaptırılan ve tekkenin yerine daha önceden yapılmış olan hamamdan alır. Hasan Basri Öcalan, Bursa'da Tasavouf Kültürü (XVII. Yüzyıl), (Bursa: Gaye Kitapevi, 2000), 128.

32 Şemseddin, Yâdigâr-ı Şemsî, 336.

33 Mermutlu - Öcalan, Tarihi Bursa Mezar Taşları II Emir Sultan, 477. 
kırmızı bir çerçeve içine alınmış istifte, Amme Sûresi'nin ilk 15 âyet-i kerimesi müdevverdir. Ayetlerde $ح$ ve $\varepsilon$ harflerinin geçtiği ifadeler, istifin alt kısmına çanaklı olarak yazılmış ve bu harflere keşide verilmiştir. Keşideler yazının ortasında yıldıza benzer bir geometrik şekil oluşturacak biçimde uzatılmıştır. Ayetlerdeki diğer ifadeler, keşidelerin arasına yerleştirilmiştir. Doğu ve batı duvarındaki istifler aynı olmalarına rağmen, aralarında bazı farklılıklar bulunur. Bu farklılıklar; doğu duvarında keşideler arasındaki yazıların yeşil renkle (Fotoğraf 5), batı duvarında ise kırmızı renkle yazılmış olması (Fotoğraf 6) ile doğu duvarındaki yazının geometrik şeklinin içinde hattatın ketebesi yer alırken, batı duvarında Ahmet Vefik Paşa'nın isminin geçmiş olmasıdır. İbrâhim Efendi ketebesini şöyle atmıştır: "imâm-ı evvel hâla, meşekkahû İbrâhim". (Fotoğraf 7) Bu ifadeden anlıyoruz ki İbrâhim Efendi yazıyı yazdığı esnada Yeşil Camii imamlığı yapmaktadır. Batı duvarındaki ifade ise şöyledir: "rattebehû Ahmed Vefik Paşa". ${ }^{34}$ (Fotoğraf 8) Her ne kadar hattat, yazıya tarih koymamış olsa da Ahmet Vefik Paşa'nın isminin burada geçmesi, bize yazının tarihleri hakkında fikir verir. Zaten M. Şemseddin (Ulusoy) Efendi, İbrâhim Efendi ile Ahmed Vefik Paşa ${ }^{35}$ arasındaki irtibattan da bahseder. ${ }^{36} \mathrm{Bu}$ yazıların da 1855 Bursa depremi sonrasında Ahmed Vefik Paşa tarafından gerçekleştirilen Bursa'daki imar faaliyetleri 37 esnasında yazıldığı anlaşılmaktadır. Yeşil Camii ve türbe için keşif yapan Mühendis Leon Parville, Ahmed Vefik Paşa tarafından davet edilmiş ve kendisine bu iş için 3000 kuruş maaş ödenmiştir. Bununla alakalı Başbakanlık Osmanlı Arşivi'nde bir belge mevcuttur ve belgenin tarihi, 1863 (H. 1280)' dir. ${ }^{38}$

2-) İbrâhim Efendi'nin, Bursa Ulu Cami'nin doğu duvarında ve kıble yönüne göre kapının sol üst tarafın yer alan 1880 (H. 1298) tarihli yazısı, 100 x $310 \mathrm{~cm}$. ölçüsünde ve $85 \mathrm{~cm}$ yüksekliğindedir. ${ }^{39}$ Duvar zemini üzerine siyah renkle ve sülüs hattıyla "ekmelü'l-mü'minîne imânen ahsenühüm hulükan" 40

34 Ekrem Hakkı Ayverdi, Osmanlı Mi 'mârîsinde Çelebi ve II. Sultan Murad Devri isimli eserinde, Yeşil Camii’ni anlattığı kısımda bu yazılarla alakalı sadece bu ifadelerden bahseder ve başka bir bilgi aktarmaz. Diğer akademik çalışmalarda da aynı durum söz konusudur. Ekrem Hakkı Ayverdi, Osmanlı Mi 'mârîsinde Çelebi ve II. Sultan Murad Devri 806-855 (1403-1451) II, (İstanbul : İstanbul Fetih Cemiyeti, 1989), 61.

35 Ahmed Vefik Paşa, Osmanlı Devleti'nin önemli devlet adamlarındandır. 1863-1864 yılında Bursa'da müfettişlik, 1879-1882 yılları arasında da Bursa valiliği yapmıștır. Șehirde yapmıș olduğu imar faaliyetleriyle bilinir. Ahmed Vefik Paşa ve bu faaliyetleri hakkında bilgi için bkz. Kübra Uslu, "Ahmed Vefik Paşa ve Bursa'nın Modernleşmesi Üzerine Bir İnceleme”, (Yayınlanmamış Yüksek Lisans Tezi, Marmara Üniversitesi Sosyal Bilimler Enstitüsü, İstanbul, 2019).

36 Şemseddin, Yâdigâr-ı Şemsî, 341.

37 Konuyla alakalı bilgi için bkz. Beatrice Saint Laurent, "Bir Tiyatro Amatörü Ahmet Vefik Paşa ve 19. Yüzyılın Son Çeyreğinde Bursa'nın Yeniden Biçimlenmesi”, Modernleşme Sürecinde Osmanlı Kentleri, ed. Paul Dumont - Françoıs Georgeon, (Ankara: Tarih Vakfi Yurt Yayınları, 1999), 78-98.

38 Doğan Yavaş, "Bursa Yeşil Cami' de Yapılan Onarımlar", Türk Dünyası Araştırmaları 183 (Aralık 2009): 593.

39 Kâzım Baykal, Bursa'da Ulu Cami, (İstanbul: İbrâhim Horoz Basımevi, 1950), 114.

40 "Müminlerin iman yönünden en kâmili, ahlakı en güzel olandır." 
ف hadis-i şerîfi yazılmıştır. ${ }^{41}$ Hattat ketebesini, yazının sol tarafında yer alan harfinin keşidesinin içine yerleştirmiştir. (Fotoğraf 9)

3-) Bursa Yıldırım Cami içindeki hiçbir yazıda İbrâhim Efendi'nin imzası ve yazılara dair herhangi bir tarih bulunmasa da, hem M. Şemseddin Efendi'nin verdiği bilgilerden hem de mükerrer yazılardan dolayı yazıların İbrâhim Efendi'ye ait olduğu kolaylıkla anlaşılmaktadır. İbrâhim Efendi'nin bu cami için yeni bir yazı yazmak yerine, elinde var olan yazı kalıplarını burada tekrar kullandığı görülmektedir. Caminin mihrab duvarının sol tarafında Bursa Ulu Cami'deki hadis-i şerîf yazılı istifin aynısı siyah bir çerçeve içine alınarak yazılmıştır. (Fotoğraf 10) Hadis-i şerîfin üstünde yuvarlak istif halinde İhlâs Sûresi yer alır. (Fotoğraf 11) Yeşil Cami'deki Amme Sûresi ise yine aynı istifle caminin doğu ve batı duvarına nakşedilmiştir. (Fotoğraf 12) Buradaki yazıların Yeşil Cami'dekilerden farkları, yazıda bütünüyle siyah renk tercih edilmesi, ortadaki geometrik şeklin Yeşil Cami'dekine nispeten daha muntazam ve sekiz kollu bir yıldız şeklinde olması ile yıldızın ortasındaki ketebe yerine "sadakallahu'l-'azîm" yazılmasıdır. Ayrıca bu camide yazının çerçevesi Barok tarzdadır. ${ }^{42}$ Yıldırım Cami'nde İbrâhim Efendi'ye ait olduğunu düşündüğümüz bir yazı daha vardır ki o da müsenna olarak sülüs hattıyla yazılmış "Besmele-i şerîf"dir. Doğu ve batı duvarında, Amme Sûresi'nin yanında yer alan bu besmele, müsenna yazılarak bir vazo şekline getirilmiştir. (Fotoğraf 13) Bu istifin Hacı Mehmed Şevkî Efendi Dergâhı'nın cümle kapısından içeri girince, kapının sağ ve sol tarafındaki mevcut çeşmelerin üstünde (Fotoğraf 14) de var olduğunun bilinmesi, bizi bu düşünceye sevk etmiştir. Yıldırım Cami'nde bu yazılardan başka yine sülüs hattıyla yazılmış çihâr yâr-i güzîn ve Hasaneyn takımı (Fotoğraf 15,16) mihrabın sağ duvarında üstte "Rabbi onu güzel bir kabulle karşıladı, güzel bir bitki gibi yetiştirdi" mealindeki âyet-i kerîme ${ }^{43}$, altta ise "nereye dönerseniz Allah'ın yüzü oradadır" mealindeki âyet-i kerîme bulunur.44 (Fotoğraf 16) ${ }^{45}$ Anlaşılan odur ki Yıldırım Cami'nin mihrabı üzerine yazılmış

\footnotetext{
1 Yazının bilgileri ve görseli için ayrıca bkz. Bilal Kemikli (ed.), Bursa Ulu Cami, (Bursa: Bursa Büyükşehir Belediyesi Kültür A.Ş. Yayınları, 2012), 252-253.

42 Yıldırım Cami'ndeki ve Bursa'daki diğer camilerde bulunan Barok tarzı süslemelerle ilgili olarak bkz. Eser Çalıkuşu, Bursa Dinî Mimarisinde Türk Barok Bezemeleri, (Ankara: Bursa İl Özel İdaresi Yayınları, 2010).

43 Âl-i İmrân, 3/ 37.

44 El-Bakara, 2/115.

45 Bursa Yıldırım Cami'nin bugünlerde hâlâ devam eden restorasyonu çalışmaları esnasında minberde kurulan iskele sebebiyle bu yazılar tam olarak görülememektedir, bu nedenle fotoğrafları çekilememiştir. Ancak, Fotoğraf 16'da yazılar kısmen görülür. Yazıların fotoğrafları için bkz. Ayverdi, Osmanlı Mi'mârîsi'nin İlk Devri, 435.
} 
yazılar ve ism-i Celal ile ism-i Nebî dışındaki bütün hüsn-i hat yazıları İbrâhim Efendi'nin elinden çıkmıştır.

\section{Hattat İbrâhim Efendi'ye Ait Yazı Kalıpları}

M. Safiyyüddin Erhan'ın özel koleksiyonunda bulunan İbrâhim Efendi'ye ait yazı kalıpları, İbrâhim Efendi'nin Bursa Ulu Cami, Yeşil Cami, Yıldırım Cami'nde yer alan yazılarının kalıplarıdır. Bunlardan başka bir de "ya hazret-i Isa sallallâhü aleyhi ve's-sellem" yazılı bir kalıp daha mevcuttur. Kalıplarının hepsi murabbaât (satranç/kareleme) yöntemiyle ${ }^{46}$ bölümlere ayrılmıştır. Sayfanın üst kısmındaki sütunlara numara verilmiştir. Kurşun kalemle harfler yazıldıktan sonra, harflerin etrafı iğneyle delinmiştir. ${ }^{47}$ Sadece "ya hazret-i Isa" kalıbı karelere ayrılmamış, siyah mürekkeple yazılmış ve hattatın ketebesi vardır. İmzasını "İbrâhim" olarak atmıştır. (Fotoğraf 17) Diğer kalıplarda imza bulunmaz. Koleksiyonda bulunan diğer yazı kalıpları ise şöyledir;

1-) Amme Sûresi yazı kalıpları, İbrâhim Efendi'nin hem Bursa Yeşil Cami'de hem de Bursa Yıldırım Cami'ndeki yazılarına aittir. Kalıp, kurşun kalemle karelere ayrılmış kâğıt üzerine harf konturları mürekkeple belirlenerek hazırlanmıştır. Keşidelere mürekkeple başlanmış, devamı kurşun kalemle tamamlanmıştır. Orta kısmı boş bırakılmış, yani yazıların orijinalinde gördüğümüz geometrik şekil oluşturulmamış, ketebe veya diğer ifadeler eklenmemiştir. (Fotoğraf 18) Keşideler arasında kalan kısımlar, mürekkeple yazılmıştır. Yazı kalıbı 52 x $52 \mathrm{~cm}$ ölçülerindedir. Yazının bütün halindeki kalıbından başka, keşideler arasında kalan kısımların ayrı ayrı yazıldığ 1 kalıplar da bulunur ki bunların sayısı 16' dır. Zaten 16 kalıba ayrı ayrı numara verilmiştir. Numaralandırma "Besmele-i şerîf" ile başlar. (Fotoğraf 19) Bu kalıplar da ortalama 30 × 40 cm. ebatlarındaki kâğıtlara, kareleme yöntemiyle ve kurşun kalemle harf konturları belirlenerek hazırlanmıştır. (Fotoğraf 20, 21)

2-) Bursa Ulu Cami ve Bursa Yıldırım Cami duvarındaki “ekmelü'lmü'minîne imânen ahsenühüm hulükan" hadis-i şerîf yazısının kalıbı da

\footnotetext{
46 Celî yazıların hazırlanmasında kullanılan bir yöntemdir. Murabbaât usûlüyle ilgili geniş bilgi ve örnek için bkz. Mahmud Bedreddin Yazır, Kalem Güzeli, ( Ankara: Diyanet İşleri Başkanlığı Yayınları, 1972), III, 312315.

47 Yazı iğneleme usûlü için bkz. Yazır, Kalem Güzeli, 315-317. Konu hakkında ayrıca bkz. Uğur Derman, “Türk Hat Sanatında "Celî” Kavramı", Türkler Ansiklopedisi, (Ankara: Yeni Türkiye Yayınları, 2002), XII, 407-419.
} 
kareleme yöntemiyle hazırlanmış ve harf konturları kurşun kalemle belirlenmiştir. Kalıp yaklaşık olarak 60 × 20 cm. ebatlarındadır. (Fotoğraf 22)

3-) Bursa Yıldırım Cami ve Hacı Mehmed Şevkî Efendi Dergâhı'ndaki çeşme üzerinde yer alan Besmele-i şerîf'in kalıbı yine aynı tarzda karelenerek hazırlanmış kâğıda kurşun kalemle yazılmıştır. Yazının aslı müsenna olsa da kalıpta tek bir yazı halindedir. (Fotoğraf 23)

\section{Sonuç}

Bursa Yeşil Cami İmamı ve Hacı Şevkî Efendi Dergâhı şeyhi olan İbrâhim Efendi'nin Bursa'nın en önemli ibadet mekânları olan Ulu Cami, Yeşil Cami ve Yıldırım Camileri'nde yazıları bulunur. Bu durum onun Bursa' ya hizmet etmiş önemli bir değer olduğunu ispat eder.

İbrâhim Efendi'nin büyük oğlu Mehmed Şevkî Efendi'nin de hattat olduğu bilinir. Yeşil Cami'de baba-oğulun yazıları yan yana yer almaktadır. Baba-oğulun tespit edilebilen bütün yazılarının sülüs hattıyla yazılmış olması, onların daha çok bu yazı türüyle meşgul olduğunu düşündürür. Ayrıca İbrâhim Efendi, Bursa'nın yetiştirdiği en önemli ta'lik hattatlarından ve İncirli (Eşrefzâde) ile Ahmed Gazzî Dergâhları meşihatını üstlenen Ali Sırrî Efendi'nin de eniştesidir. Buradan anlıyoruz ki hüsn-i hat sanatı bu sülale için oldukça önemli bir yere sahipti ve Bursa' da pek çok eser bırakmış hattatlar yetiştirmişti. Zaten İslam medeniyetinde hüsn-i hat ile tasavvufun içe içe olduğu, tekke-sanat birlikteliğinin birçok hattat, mûsikişinas ve şair yetiştirdiği aşikârdır. İbrâhim Efendi de şeyh ve hattatlı̆̆ı yönüyle bu duruma örnek şahsiyetlerden biridir. İbrâhim Efendi'nin hüsn-i hat sanatında hocası ve silsile itibariyle nereye bağlı bulunduğu bilinmez. Fakat M. Safiyyüddin Erhan'ın özel koleksiyonundaki kalıplardan, kendisinin geleneksel usûllere uygun çalıştığı anlaşılmaktadır.

Bursa Yeşil Cami imamı hattat İbrâhim Efendi'nin Bursa için en büyük hizmeti, kuşkusuz Yeşil Cami ile Yıldırım Cami içindeki yazılarıdır. Bu yazıların, 1855 Bursa depremi sonrasındaki onarımlardan sonra cami duvarlarına yazıldığı bilinmektedir. Yeşil Cami'nin ilk yapıldığı zamanlardan beri var olan çini tezyinatına ilaveten bu yazılar eklenmiştir. Fakat Yıldırım Camisi'ndeki İbrâhim Efendi'nin celî sülüs yazılarından başka çok az yazının var olması, caminin ilk yapıldı̆̆ı zamanlarda yazı hususunda duvarların boş kaldığı anlaşılmaktadır. 


\section{Kaynakça}

Ayverdi, Ekrem Hakkı. Osmanlı Miłmârîsinin İlk Devri (Ertuğrul, Osman, Orhan Gaazîler, Hüdavendigâr ve Yıldırım Bâyezîd 630-805 (1230-1402) I, İstanbul: İstanbul Fetih Cemiyeti, 1989.

. Osmanlı Miłmârîsinde Çelebi ve II. Sultan Murad Devri 806-855 (1403-1451) II, İstanbul : İstanbul Fetih Cemiyeti, 1989.

Azamat, Nihat. "Kuşadalı İbrâhim Efendi". Türkiye Diyanet Vakfı İslâm Ansiklopedisi (DİA), Ankara: Türkiye Diyanet Vakfı, 2002, XXVI, 468 - 470. " Osman Şems Efendi". Türkiye Diyanet Vakfı İslâm Ansiklopedisi(DİA), İstanbul: Türkiye Diyanet Vakfı, 2007, XXXIII, 473 -475.

Bayartan, Mehmet. “Osmanlı'dan Günümüze Kütahya Şehrinin Yap1 Taşları: Mahalleler". İstanbul Üniversitesi Edebiyat Fakültesi Coğrafya Bölümü Dergisi, 18 (2009): 57-70.

Baykal, Kâzım. Bursa' da Ulu Cami. İstanbul: İbrâhim Horoz Basımevi, 1950.

Çalıkuşu, Eser. Bursa Dinî Mimarisinde Türk Barok Bezemeleri. Ankara: Bursa İl Özel İdaresi Yayınları, 2010.

Derman, Uğur. “Türk Hat Sanatında “Celî” Kavramı”, Türkler Ansiklopedisi, Ankara: Yeni Türkiye Yayınları, 2002, XII, 407-419.

Erhan, Mehmed Safiyüddîn. Bir Zamanlar Bursa'ydı Bir Pâyitahtın Pâyimâli. İstanbul: Sufi Kitap, 2016.

Gabriel, Albert. Bir Türk Başkenti Bursa, haz. Neslihan Er, Hamit Er, Aykut Kazancıgil, Bursa: Osmangazi Belediyesi Yayınları, 2008.

Gülgen, Hicabi. "Ulu Cami Hatları Bursa Ulucamii Yazıları". Bursa'nın Kalbi Ulu Cami, ed. Mustafa Kara - Bilal Kemikli, 113 - 121. Bursa: Bursa İl Özel İdaresi Yayınları, 2009.

İnal, İbnülemin Mahmud Kemal. Son Hattatlar. İstanbul: Maarif Basımevi, 1955.

“İstanbul/Ahmet İzzet Efendi Külliyesi". Erişim Tarihi: 04.03.2020. http:/ / fetihlervakfi.org.tr/faaliyet.php?id=3.

Kara, Mustafa. Bursa'da Tarîkatlar ve Tekkeler. Bursa: Osmangazi Belediyesi Yayınları, 2017.

Karacabey, Salih. "Mesajları ve Muhtevası Açısından Bursa Yeşil Cami ve Türbe İç Yazıları". Bursa'nın Tarihi Mahalleleri II (Hocataşkın, Kurtoğlu, Meydancık, Namazgah, Yeşil), 130-143. Bursa: Bursa Büyükşehir Belediyesi Yayınları, 2011.

Kemikli, Bilal (ed.). Bursa Ulu Cami. Bursa: Bursa Büyükşehir Belediyesi Kültür A.Ş. Yayinları, 2012.

Kepecioğlu, Kamil. Bursa Kütüğü. Trc. Osman Çetin, Mustafa Kara, Mefail Hızlı, Hüseyin Algül, M. Asım Yediyıldız. Bursa: Bursa Büyükşehir Belediyesi Kültür A.Ş. Yayınları, 2009.

Laurent Saint, Beatrice. "Bir Tiyatro Amatörü Ahmet Vefik Paşa ve 19. Yüzyılın Son Çeyreğinde Bursa'nın Yeniden Biçimlenmesi". Modernleşme Sürecinde Osmanlı Kentleri. Ed. Paul Dumont - Franço1s Georgeon, 79-98. Ankara: Tarih Vakfı Yurt Yayınları, 1999.

Mermutlu, Bedri - Öcalan, Hasan Basri. Tarihi Bursa Mezar Taşları II Emir Sultan Mezarlığı. Bursa: Bursa Büyükşehir Belediyesi Kültür A.Ş. Yayınları, 2012.

Öcalan, Hasan Basri. Bursa'da Tasavvuf Kültürü (XVII. Yüzyıl). Bursa: Gaye Kitapevi, 2000. 
Öztürk, Yaşar Nuri. Kutsal Gönüllü Velî Kuşadalı İbrâhim Halvetî (Hayatı, Düşünceleri, Mektupları). İstanbul: Fatih Yayınevi, 1982.

Şemseddin, Mehmed. Bursa Dergâhları Yâdigâr-1 Şemsî I-II, haz. Mustafa Kara - Kadir Atlansoy. Bursa: Uludă̆ Yayınları, 1997.

Tanman, M. Baha. “Aydınoğlu Tekkesi”. Türkiye Diyanet Vakfı İslâm Ansiklopedisi (DİA), İstanbul: Türkiye Diyanet Vakf1, 1991, VI, 238-239.

Tüfekçioğlu, Abdülhamit. Erken Dönem Osmanlı Mimarîsinde Yazı, Ankara: Kültür Bakanlığı Yayınları, 2001.

Uslu, Kübra. “Ahmed Vefik Paşa ve Bursa'nın Modernleşmesi Üzerine Bir İnceleme”. Yayınlanmamış Yüksek Lisans Tezi, Marmara Üniversitesi Sosyal Bilimler Enstitüsü, İstanbul, 2019.

Vassâf, Osmânzâde Hüseyin. Sefîne-i Evliyâ I. haz. Mehmet Akkuş - Ali Yılmaz. İstanbul: Seha Neşriyat, 1990.

. Sefine-i Evliyâ IV. haz. Mehmet Akkuş - Ali Yılmaz. İstanbul: Kitabevi, 2006.

Yavaş, Doğan. “Bursa Yeşil Cami' de Yapılan Onarımlar”. Türk Dünyası Araştırmaları 183 (Aralık 2009): 589-598.

Yazır, Mahmud Bedreddin. Kalem Güzeli. Ankara: Diyanet İşleri Başkanlığı Yayınları, 1972. 


\section{Fotoğraflar}

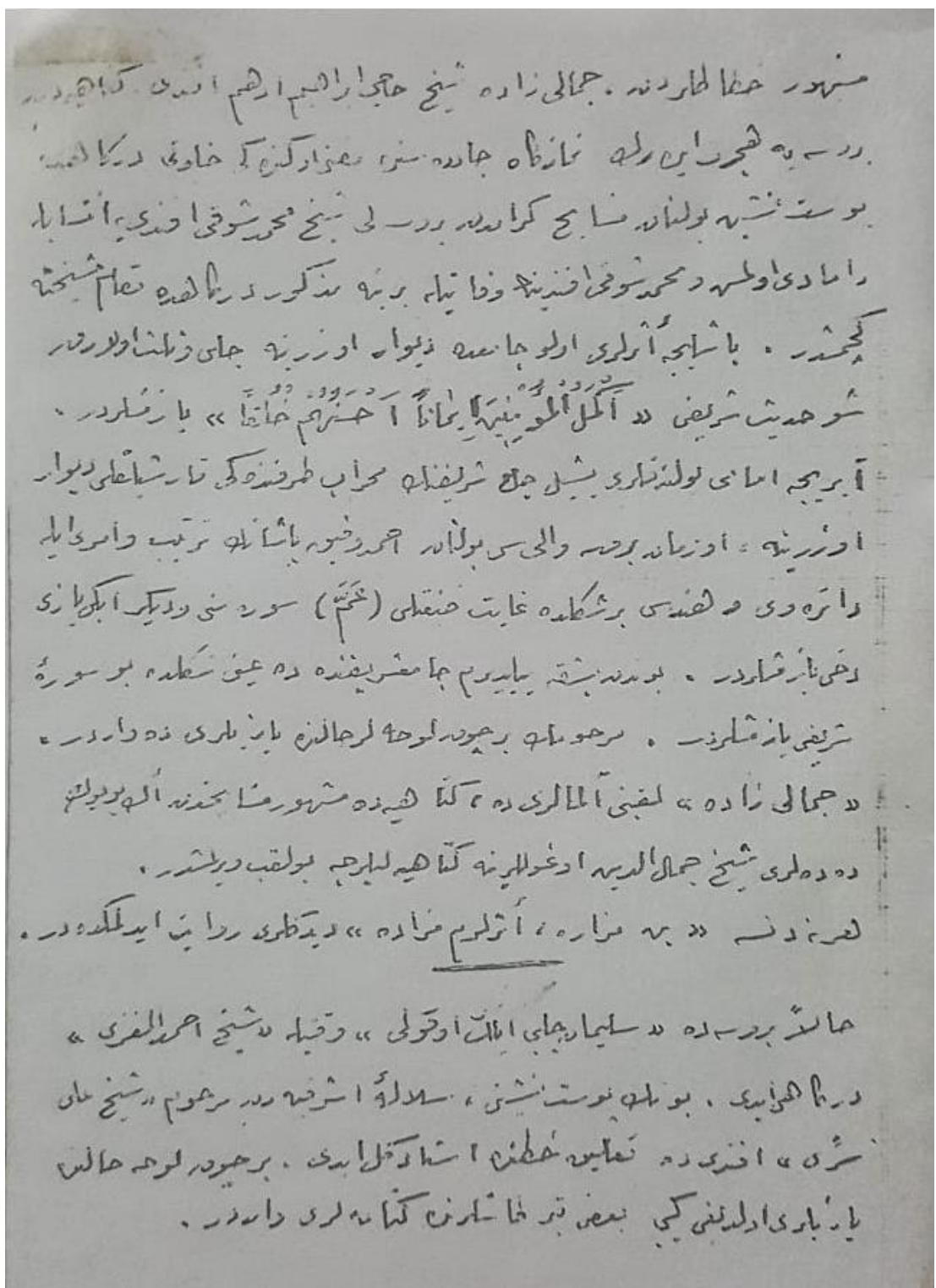

Fotoğraf 1. İbrâhim Efendi'yle alakalı bilgi notu (M. Safiyüddin Erhan Arşivi) 


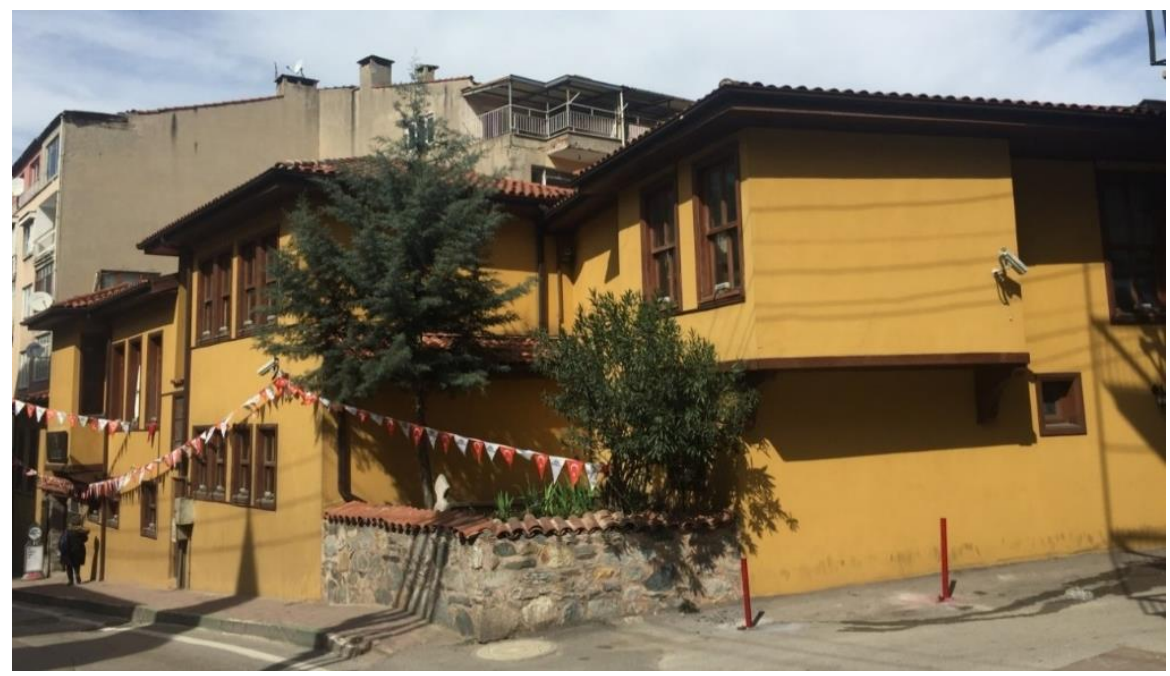

Fotoğraf 2. Bursa Hacı Mehmed Şevkî Efendi Dergâhı'nın

Vakıflar Bölge Müdürlüğü tarafından gerçekleştirilen rekonstrüksiyon sonrası hali

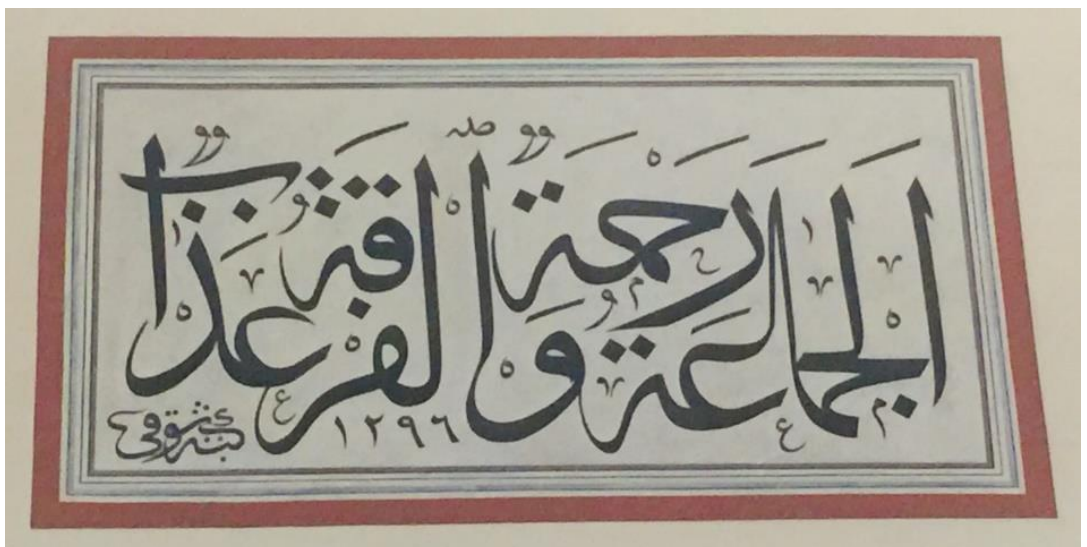

Fotoğraf 3. Mehmed Şevkî Efendi'nin Bursa Yeşil Cami harim kısmı Doğu duvarındaki yazısı 


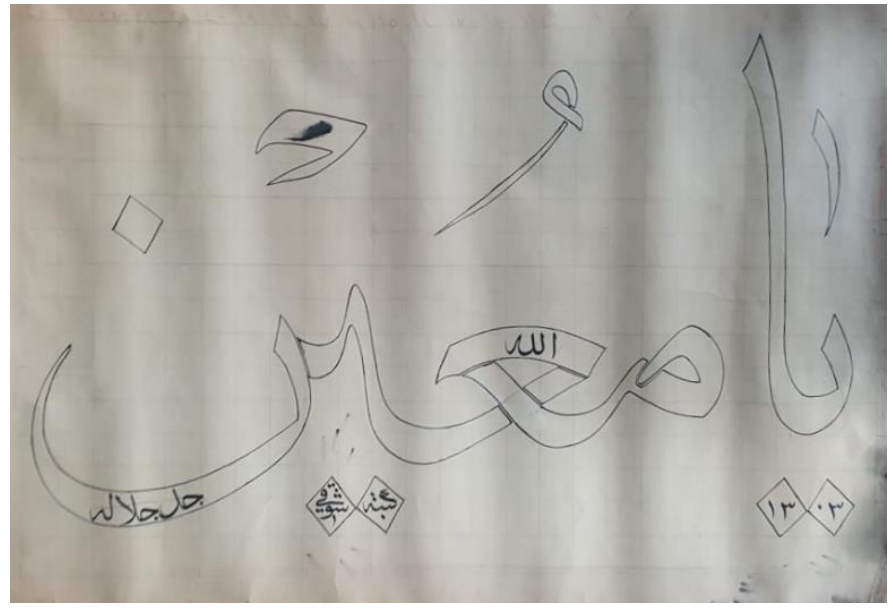

Fotoğraf 4. Mehmed Şevkî Efendi'nin

"Ya Mu'̂ิn" yazı kalıbı (M. Safiyyüddin Erhan Özel Koleksiyonu)

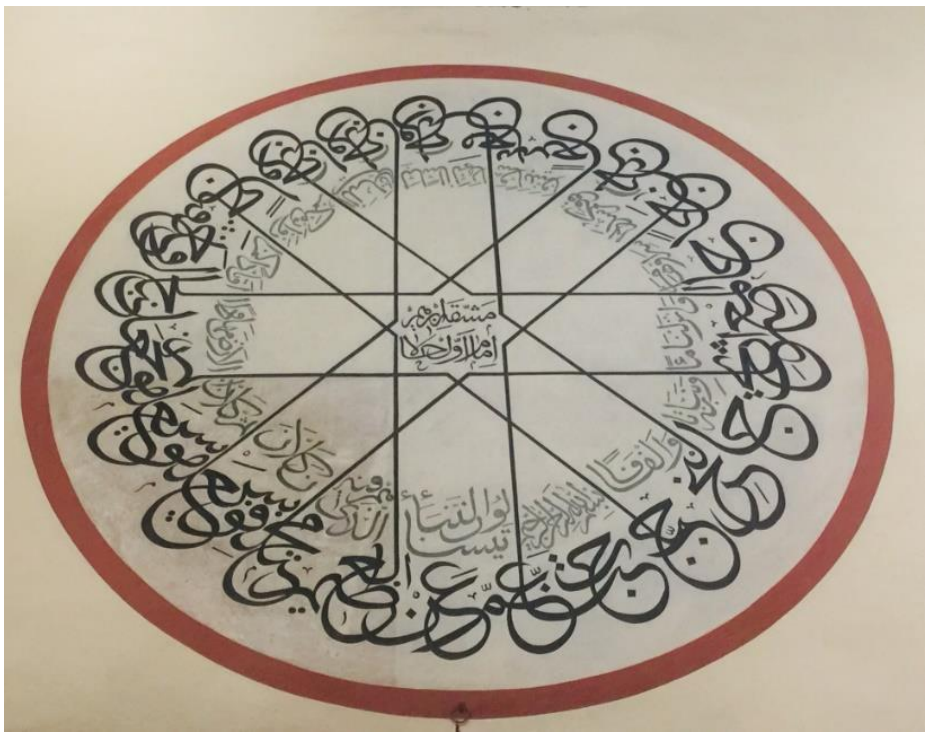

Fotoğraf 5. İbrâhim Efendi'nin Bursa Yeşil Cami harim kısmı doğu duvarındaki Yazısı 


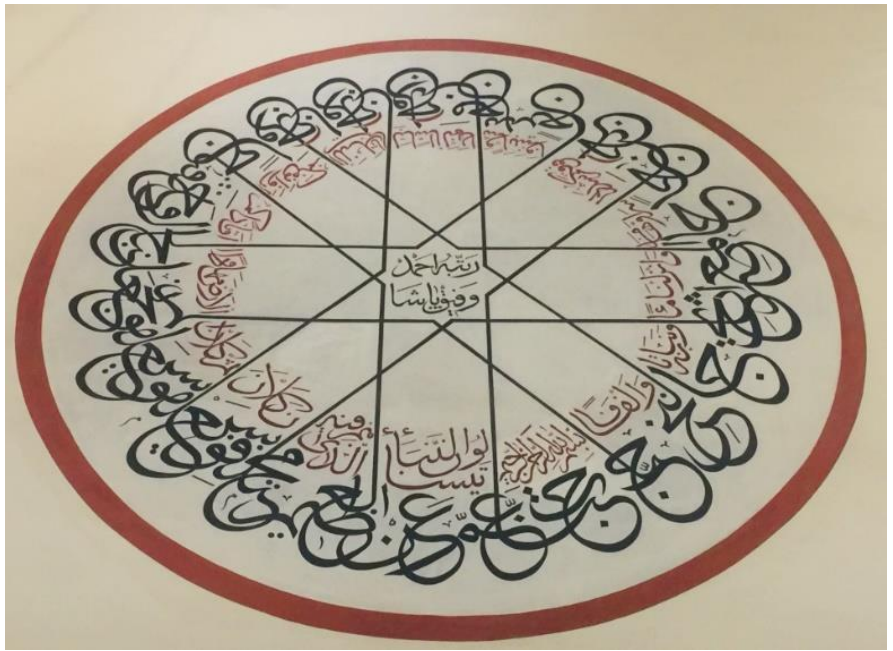

Fotoğraf 6. İbrâhim Efendi'nin Bursa Yeşil Cami harim kısmı batı duvarındaki yazısı

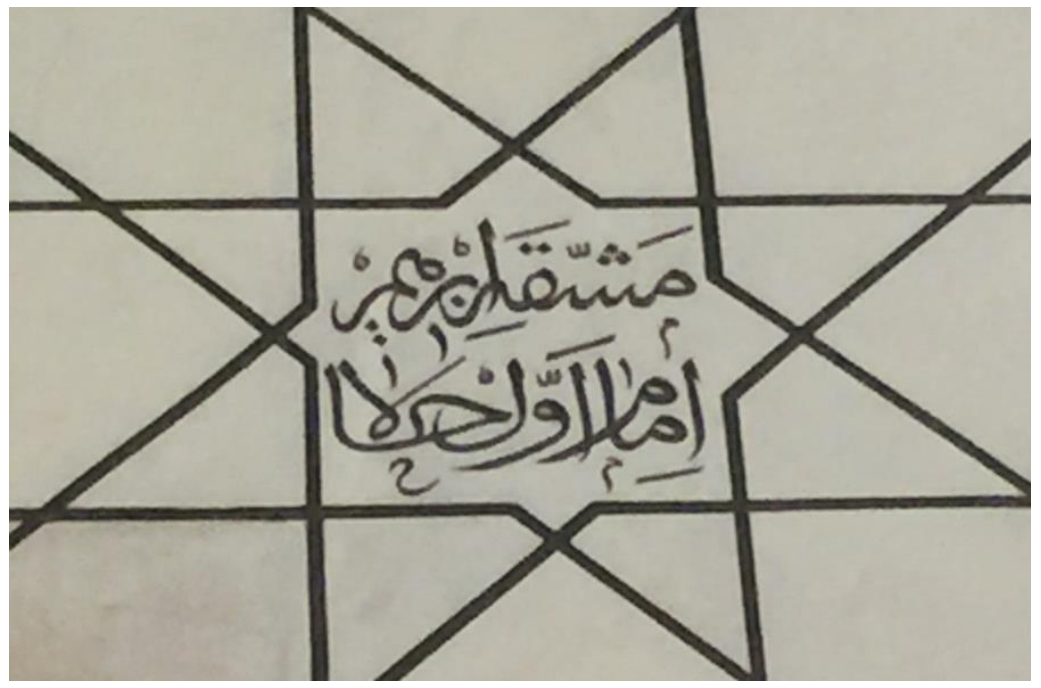

Fotoğraf 7. İbrâhim Efendi'nin Amme Sûresi istifi ortasındaki ketebesi (doğu duvarı) 


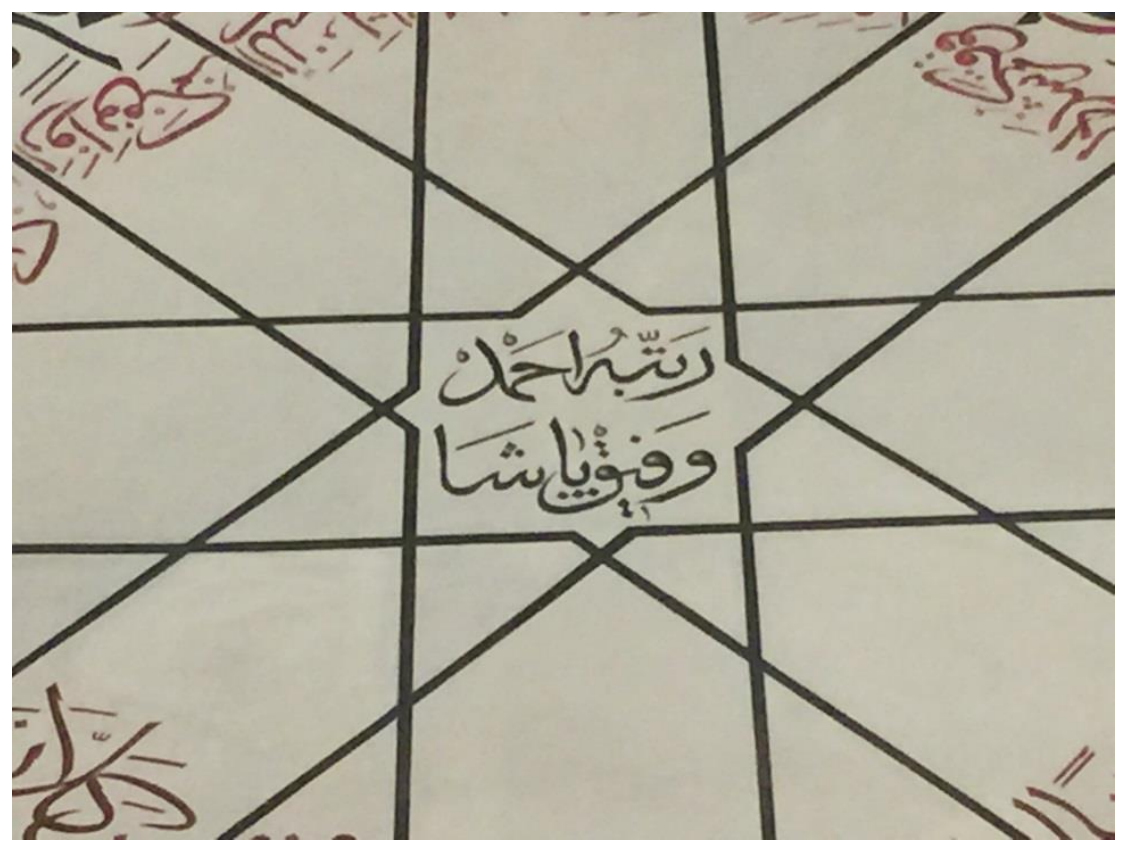

Fotoğraf 8. Amme Sûresi istifi ortasındaki Ahmed Vefik Paşa ibaresi (bat1 duvar1)

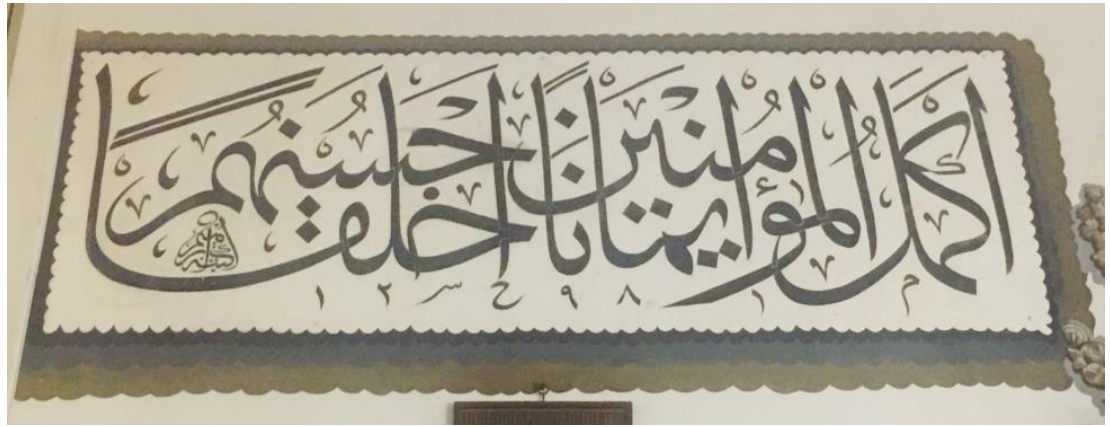

Fotoğraf 9. İbrâhim Efendi'nin Bursa Ulu Cami doğu duvarındaki 1880 (H. 1298) yazıs1 


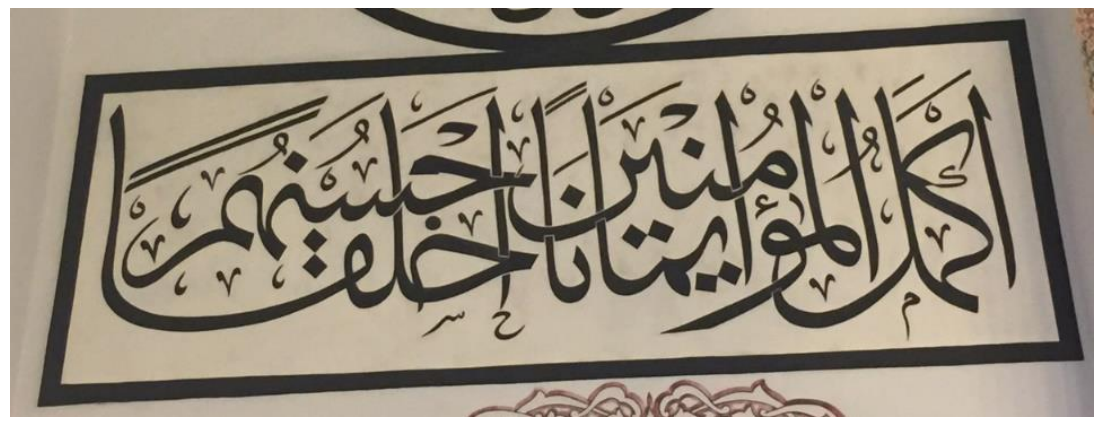

Fotoğraf 10. Bursa Yıldırım Cami harim kısmı mihrap duvarındaki Hadis-i şerîf

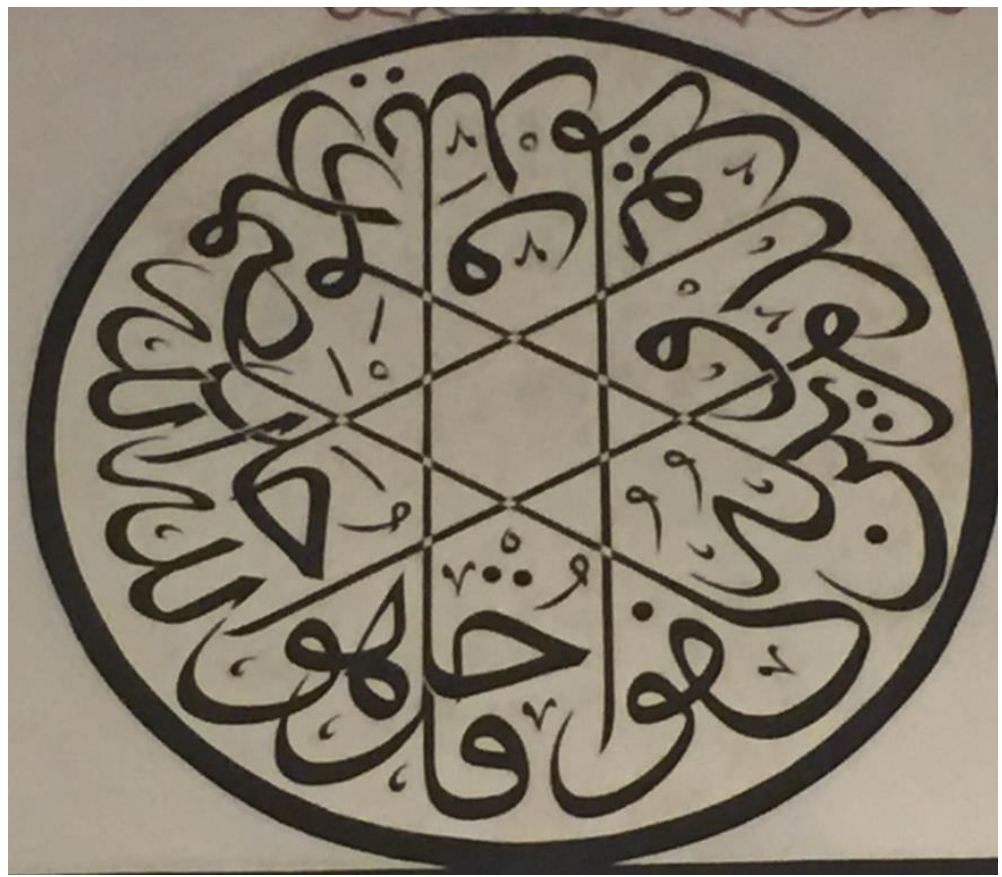

Fotoğraf 11. Bursa Yıldırım Cami harim kısmı mihrap duvarındaki İhlas Sûresi 


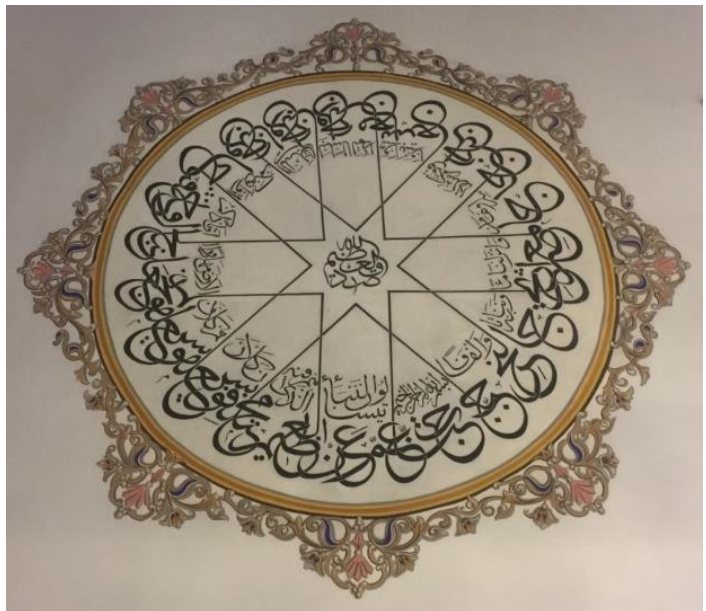

Fotoğraf 12. Bursa Yıldırım Cami harim kısmı doğu ve batı duvarındaki Amme Sûresi

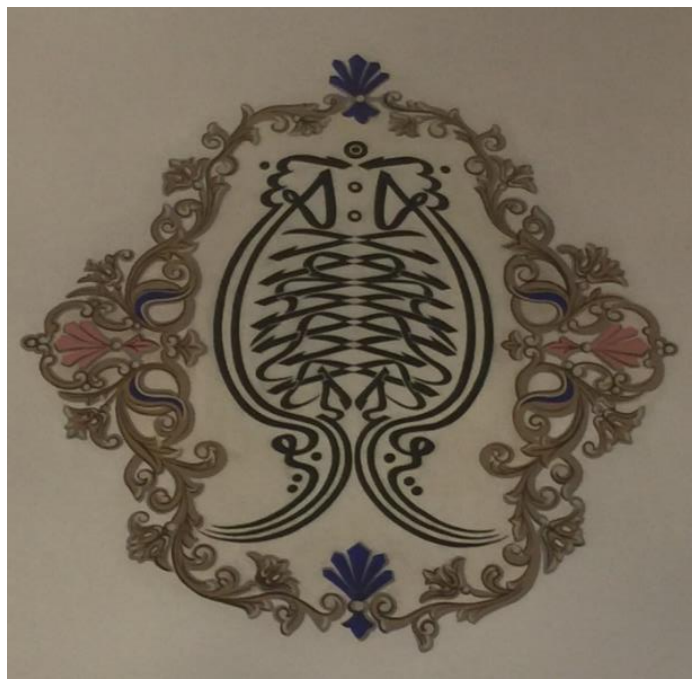

Fotoğraf 13. Bursa Yıldırım Cami harim kısmı doğu ve batı duvarındaki müsenna Besmele-i şerîf 


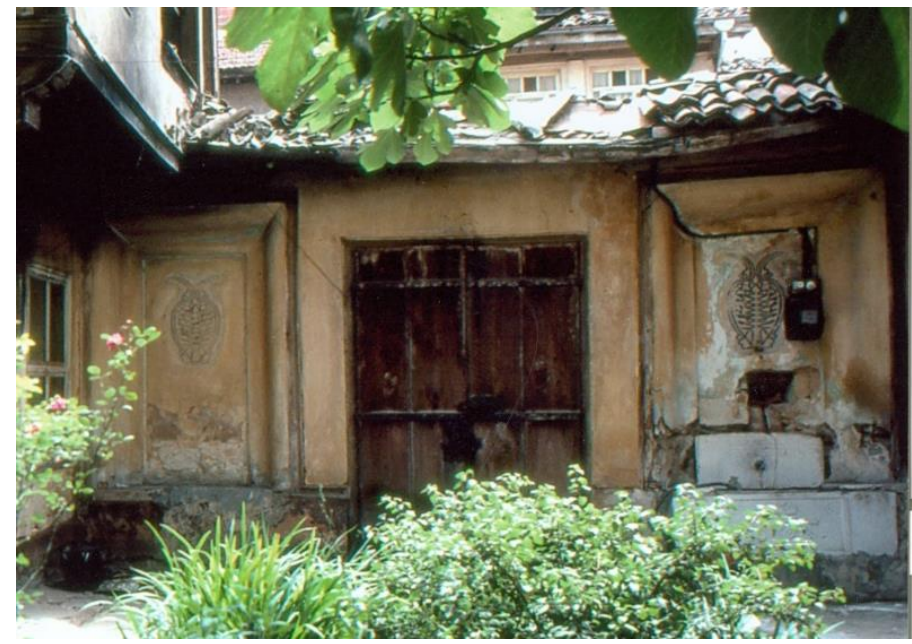

Fotoğraf 14. Bursa Hacı Mehmed Şevkî Efendi Dergâhı'ndaki müsenna Besmele-i Şerîf (M. Safiyyüddin Erhan Arşivi)

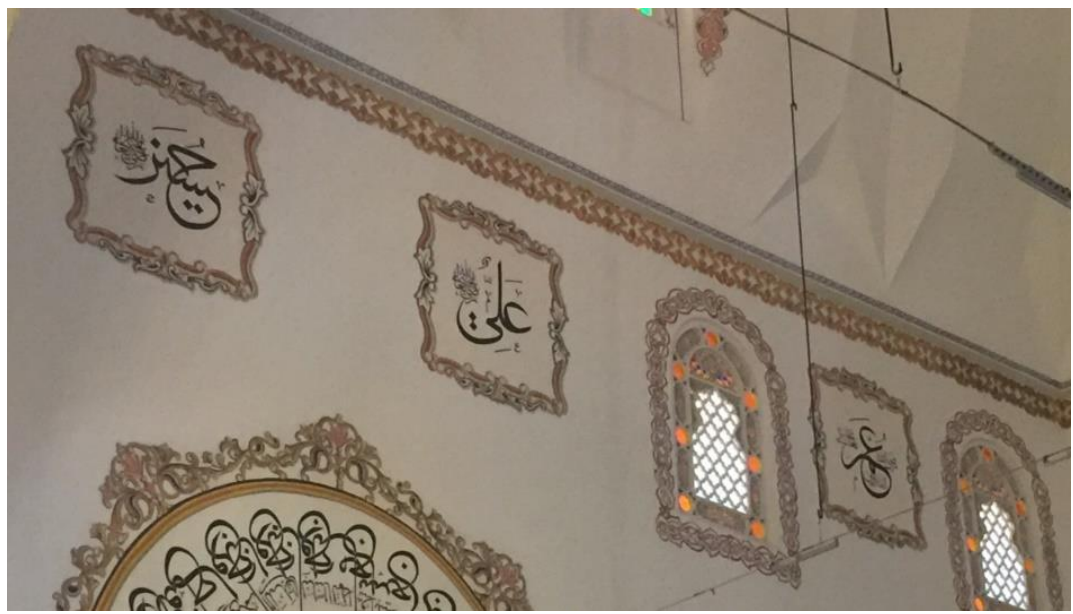

Fotoğraf 15. Bursa Yıldırım Cami doğu duvarındaki Hz. Ömer, Hz. Ali ve Hz. Hüseyin (ra) isimleri 


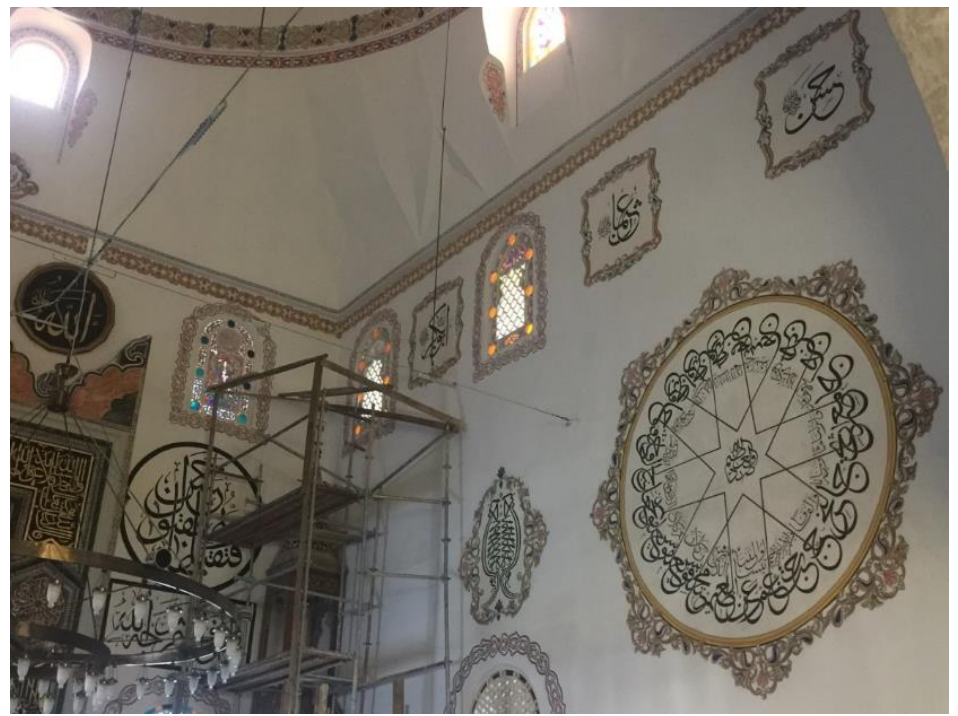

Fotoğraf 16. Bursa Yıldırım Cami batı duvarındaki Hz. Ebubekir, Hz. Osman ve $\mathrm{Hz}$. Hasan (ra)'in isimleri

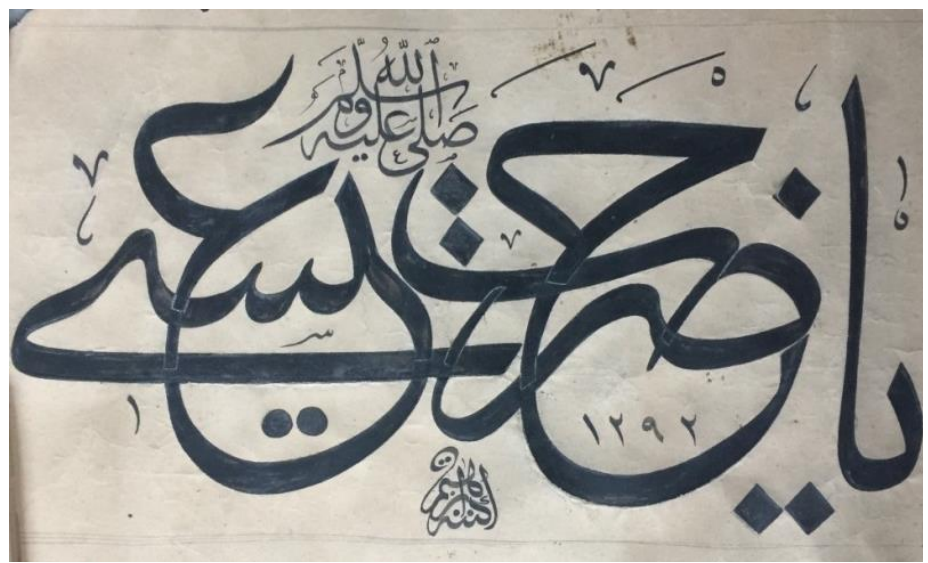

Fotoğraf 17. "Ya Hazret-i İsa sallallâhü aleyhi ve's-sellem" iğneli yazı kalıbı (M. Safiyyüddin Erhan Özel Koleksiyonu) 


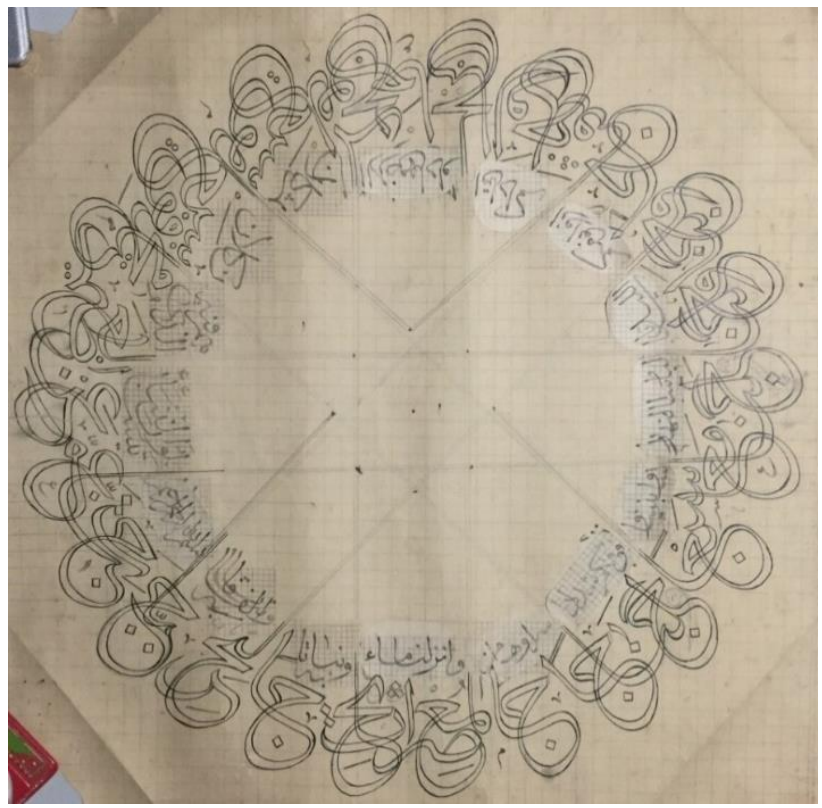

Fotoğraf 18. Amme Sûresi yazı kalıbı (M. Safiyyüddin Erhan Özel Koleksiyonu)

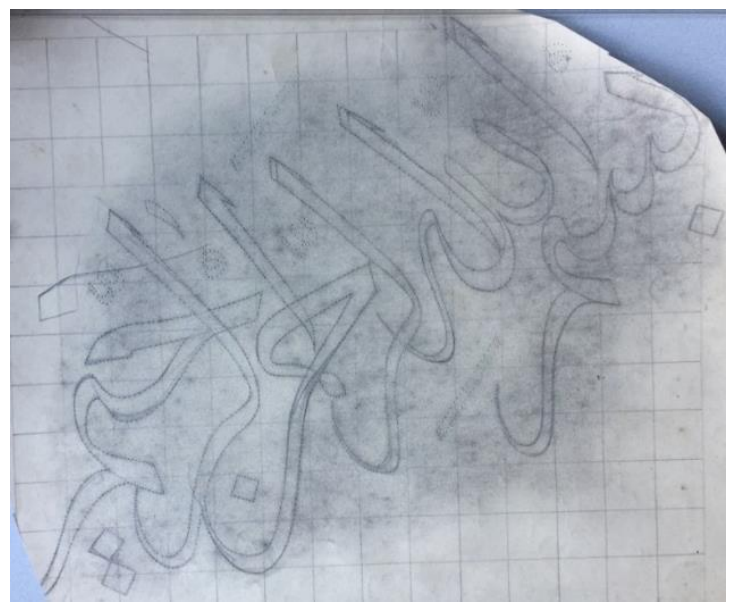

Fotoğraf 19. Amme Sûresi'nin Besmele-i şerîf (1 nolu) yazı kalıbı (M. Safiyyüddin Erhan Özel Koleksiyonu) 


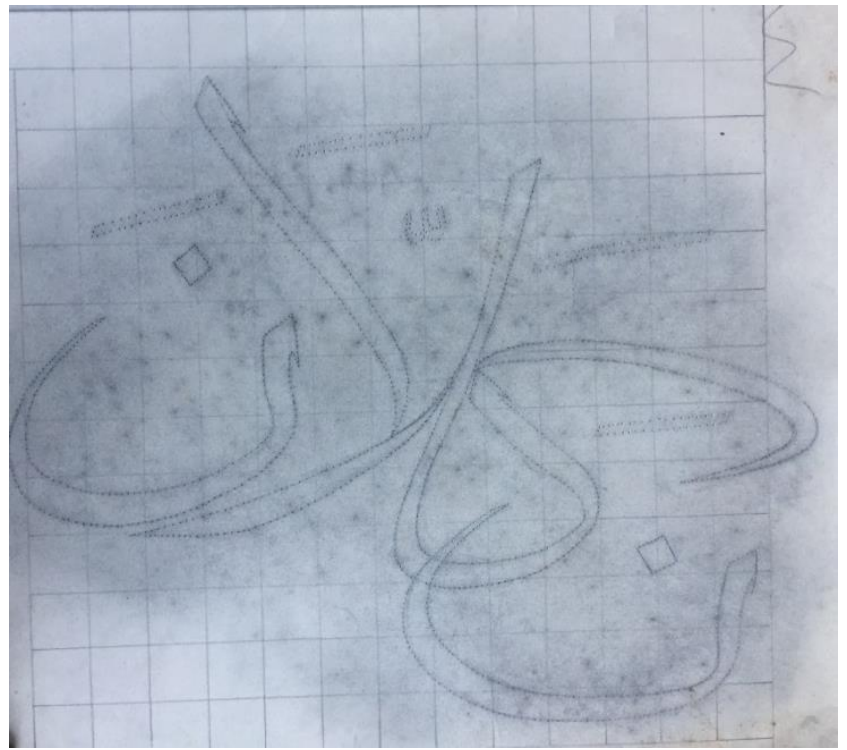

Fotoğraf 20. Amme Sûresi'nin 4 numaralı yazı kalıbı (M. Safiyyüddin Erhan Özel Koleksiyonu)

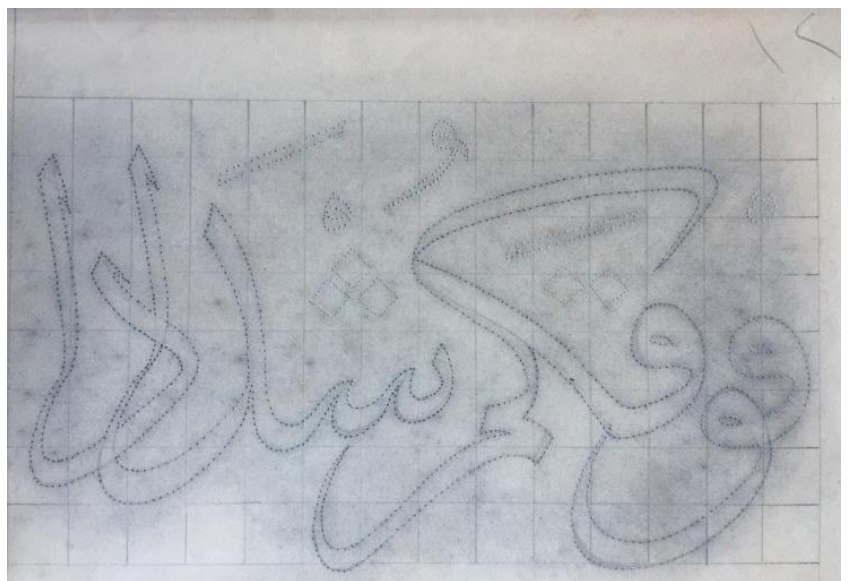

Fotoğraf 21. Amme Sûresi'nin 12 numaralı yazı kalıbı (M. Safiyyüddin Erhan Özel Koleksiyonu) 


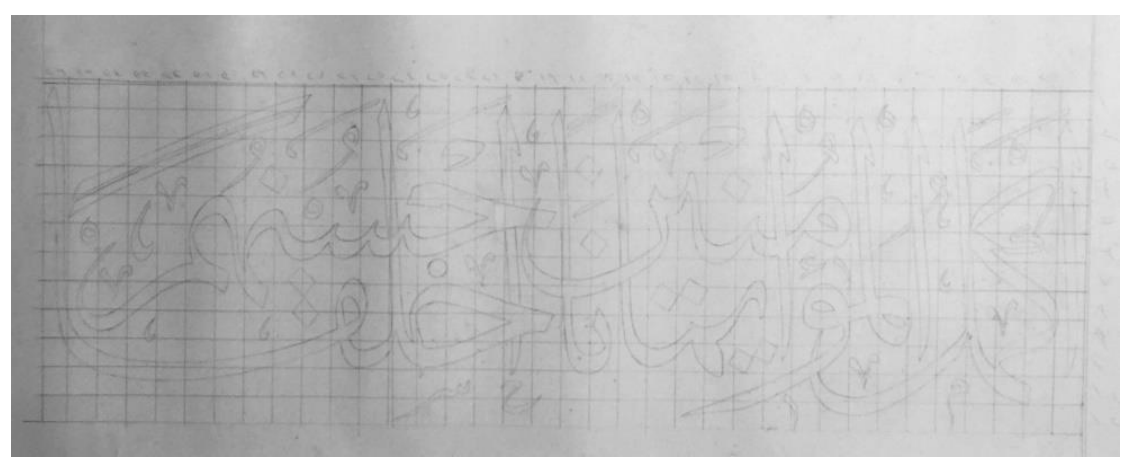

Fotoğraf 22. Bursa Ulu Cami ve Yıldırım Cami'ndeki Hadis-i şerîfin yazı kalıbı (M. Safiyyüddin Erhan Özel Koleksiyonu)

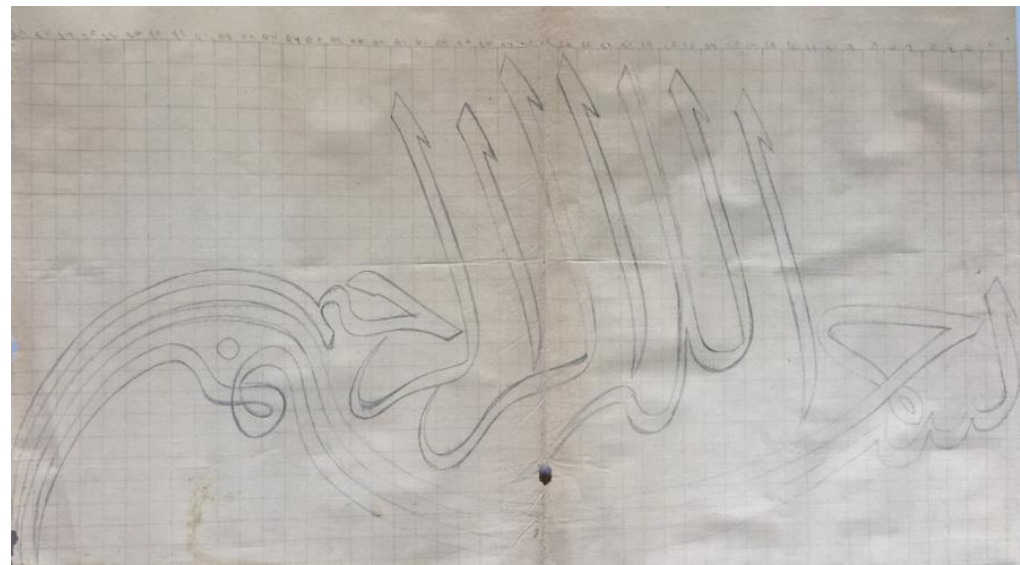

Fotoğraf 23. Bursa Yıldırım Cami ve Hacı Mehmed Şevkî Efendi Dergâhı'nda bulunan müsenna Besmele-i şerîf yazısının yazı kalıbı (M. Safiyyüddin Erhan Özel Koleksiyonu) 


\section{Semra Güler}

\section{Calligrapher Ibrahim Efendi The Imam of Bursa Green Mosque}

Citation/@: Güler, Semra Calligrapher Ibrahim Efendi The Imam of Bursa Green Mosque, Artuklu Akademi, 2020/7 (1), 1-28.

\section{Extended Abstract}

It is not a coincidence that most of the famous Ottoman calligraphers were sufis. In the setting where mysticism and art interact, not only calligraphers but also great poets and musicians have grown up. The subject of this article, Ibrahim Efendi was both a calligrapher and a sheikh. He also served as imam at the Bursa Green Mosque.

The existing data related to Ibrahim Efendi is fairly limited. We collect the information about his life and works from Mehmed Şemseddin Efendi's Yadiga r-

I Shamsi, and another information is found in the archive of Mehmed

Safiyyuddin Erhan in an anonymous one-page information note written in riq'ah style. It is understood from this information that Ibrahim Efendi's father and grandparents were from Kütahya. It was due to his grandfather Sheikh Cemaleddin Efendi that Ibrahim Efendi's family was called as "Cema-liza-de" in Kütahya. No information has been reached about who Sheikh Cemaleddin Efendi was. However, the fact that Cemaleddin Neighborhood in Kütahya is one of the oldest neighborhoods in Kütahya brings to mind the question whether there might be a connection between him and the setting. The same scholar made Ibrahim Efendi's father Cemalizade Seyyid Mehmed Efendi and Bursalı Hac1 Mehmed Şevki Efendi meet on common ground due to the fact that both were the followers of Kuşadalı Ibrahim Halveti-. Ibrahim Efendi married Saide Rukiyye Hanım, the daughter of Hacı Mehmed Şevki Efendi, and moved to Bursa. Ibrahim Efendi had two sons from this marriage; Mehmed Şevki Efendi and Hafız Osman Efendi. It is known that Mehmed Şevki Efendi performed calligraphy like his father and was teacher at school and that a hadi-th written by him hung on the east wall of Bursa Green Mosque sanctuary. Hafız Osman Efendi, on the other hand, accepted as the sheikhdom of Hamam Tekke (Dervish Lodge) and conducted religious rites in accord with the Qadiriyya and Sha ba niyya order's forms.

After the death of Ibrahim Efendi's father-in-law, in 1858, Sheikh Hac1 Mehmed Şevki Efendi Tekkesi, located on the left side of the Namazga $\mathrm{h}$ hill in Bursa Setbaş1 District and opposite the Müftüönü Mosque, was appointed to Ibrahim Efendi. It is known that Ismail Galib Efendi, who married the other daughter of Hac1 Mehmed Şevki Efendi, Tevhide Hanım, lived in this tekke together with Ibrahim Efendi. Ismail Galib Efendi is also the father of Ali Surrı Efendi, one of the most important ta'li q style calligraphers who lived in Bursa Incirli Tekkesi in the late Ottoman Empire. In other words, Ibrahim Efendi was the brother-in-law of Ali Sirrı Efendi. 
It is understood from the signature of Ibrahim Efendi that he worked as an imam in Bursa Green Mosque besides being the sheikh of Hacı Mehmed Şevki Efendi Tekkesi. Ibrahim Efendi passed away on July 18, 1889 and was buried in front of the Nimetullah Efendi Tomb known as Sancaktar Baba in Emir Sultan. Mehmed Şevki Efendi's tombstone still exists today and is a unique example of Halwati Sha ba ni-tombstone in Bursa. On the other hand, tombstones of Ibrahim Efendi and his sons could not be found in Bursa.

As for the the calligraphy of Ibrahim Efendi, the primary point to be mentioned is that there is hardly no information available regarding by whom he was trained and to which art school he belonged. However, it is recognized from the artworks existing today that he and his son, calligrapher Mehmed Şevki Efendi, used mostly thuluth style. The works of Ibrahim Efendi are exhibited on the walls of Bursa Grand Mosque and Bursa Green Mosque. The date of the artwork in the Bursa Grand Mosque is given, but there is no date given in the writings in Green Mosque. However, the phrase "arranged by Ahmed Vefik Pasha", located in the middle of the writings that were inscribed in a circular pattern on the east and west walls of the Green Mosque sanctuaryfacing each other, provides insight about the date of the artworks. The fact that Ahmed Vefik Pasha was a Bursa inspector between 1863 and 1864 and that he commissioned Leon Parville for the restoration of the Green Mosque strengthens this idea. It is estimated that these artworks were written during the restoration period. The calligraphy of Ibrahim Efendi in Bursa Grand Mosque, on the other hand, is a hadi-th inscribed on the wall, in the section where the mosque's east door stood and on the upper left side of the door in accordance with the direction of Qibla.

Another mosque with the writings of Ibrahim Efendi is the Bursa Yildirım Mosque. Although there are no signatures and dates stated in the artworks, the fact that Ibrahim Efendi repeated in this mosque the same calligraphy he performed in Bursa Grand Mosque and Bursa Green Mosque confirms that they were written by Ibrahim Efendi. Besides, the same composition of the vaseshaped and symmetrical calligraphy-styled Basmala-i Sharif, which is known to be located over the fountain in Hacı Mehmed Şevki Efendi Tekkesi, is visible in this mosque. In addition to these writings, the Surah al-Ikhlas composed in thuluth style, the Qur'a-nic verses saying, "God greeted her with a nice acceptance, and raised her like a beautiful plant." ('Ati-'Imran, 3/37) and "Wherever you turn, there is the face of God" ( al-Baqarah, 2/115), the calligraphy inscriptions of Jihar Yar$i$ Guzin (the friends of Prophet Muhammad: Abu-Bakr, 'Umar, 'Uthman, 'A ti-) and $H \square$ asanain (the grandsons of Prophet Muhammed: H $\square$ asan and $H \square$ ussein,) which thoroughly decorate the mosque's mih $\square$ rab wall indicates that they were all composed by Ibrahim Efendi.

It was observed in the calligraphy patterns of Ibrahim Efendi in the special collection of Mehmed Safiyyuddi-n Erhan that Ibrahim Efendi prepared the calligraphy patterns according to the method of murabbat (squaring/chess). It is understood that he considers the traditional method in his artworks. To sum up, 
Ibrahim Efendi, the imam of Bursa Green Mosque and calligrapher, was an influential person who has writings in the most important shrines of Bursa, but has not enough place allocted to him in the related sources. 